\title{
Secondary organic aerosol formation from $m$-xylene, toluene, and benzene
}

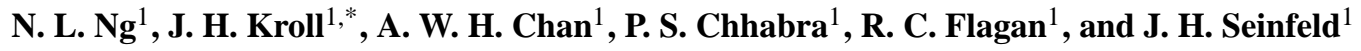 \\ ${ }^{1}$ Departments of Chemical Engineering and Environmental Science and Engineering, California Institute of Technology, \\ Pasadena, CA 91125, USA \\ * now at: Aerodyne Research, Inc. 45 Manning Road, Billerica, MA 01821, USA
}

Received: 1 March 2007 - Published in Atmos. Chem. Phys. Discuss.: 28 March 2007

Revised: 28 June 2007 - Accepted: 13 July 2007 - Published: 24 July 2007

\begin{abstract}
Secondary organic aerosol (SOA) formation from the photooxidation of $m$-xylene, toluene, and benzene is investigated in the Caltech environmental chambers. Experiments are performed under two limiting $\mathrm{NO}_{\mathrm{x}}$ conditions; under high- $\mathrm{NO}_{\mathrm{x}}$ conditions the peroxy radicals $\left(\mathrm{RO}_{2}\right)$ react only with $\mathrm{NO}$, while under low- $\mathrm{NO}_{\mathrm{x}}$ conditions they react only with $\mathrm{HO}_{2}$. For all three aromatics studied ( $m$-xylene, toluene, and benzene), the SOA yields (defined as the ratio of the mass of organic aerosol formed to the mass of parent hydrocarbon reacted) under low- $\mathrm{NO}_{\mathrm{x}}$ conditions substantially exceed those under high- $\mathrm{NO}_{\mathrm{x}}$ conditions, suggesting the importance of peroxy radical chemistry in SOA formation. Under low- $\mathrm{NO}_{\mathrm{x}}$ conditions, the SOA yields for $m$ xylene, toluene, and benzene are constant $(36 \%, 30 \%$, and $37 \%$, respectively), indicating that the SOA formed is effectively nonvolatile under the range of $M_{o}\left(>10 \mu \mathrm{g} \mathrm{m}^{-3}\right)$ studied. Under high- $\mathrm{NO}_{\mathrm{x}}$ conditions, aerosol growth occurs essentially immediately, even when NO concentration is high. The SOA yield curves exhibit behavior similar to that observed by Odum et al. (1996, 1997a, b), although the values are somewhat higher than in the earlier study. The yields measured under high- $\mathrm{NO}_{\mathrm{x}}$ conditions are higher than previous measurements, suggesting a "rate effect" in SOA formation, in which SOA yields are higher when the oxidation rate is faster. Experiments carried out in the presence of acidic seed aerosol reveal no change of SOA yields from the aromatics as compared with those using neutral seed aerosol.
\end{abstract}

\section{Introduction}

Aromatic hydrocarbons contribute an important fraction ( $\sim 20-30 \%)$ of total volatile organic compounds in the urban atmosphere (Calvert et al., 2002). Atmospheric oxidation of

Correspondence to: J. H. Seinfeld

(seinfeld@caltech.edu) aromatic hydrocarbons leads to the production of ozone as well as low-volatility species which then partition into the condensed phase, forming secondary organic aerosol (SOA).

The anthropogenic contribution to global SOA formation is currently estimated to be small, roughly about $10 \%$ (Tsigaridis and Kanakidou, 2003). Ambient measurements suggest that SOA formation in the atmosphere is higher than that predicted by current models (Heald et al., 2005, 2006; de Gouw et al., 2005; Volkamer et al., 2006). In addition, it has been suggested that SOA formation from anthropogenic sources is substantially higher than currently thought (de Gouw et al., 2005; Volkamer et al., 2006).

Gas-phase chemistry of aromatic hydrocarbons is dominated by reaction with the $\mathrm{OH}$ radical (Calvert et al., 2002). Despite considerable study of the oxidation chemistry of aromatic hydrocarbons, the basic underlying mechanisms of SOA formation and growth from aromatic precursors remain poorly understood. There have been few studies on the molecular composition of SOA from aromatic hydrocarbons (Forstner et al., 1997; Jang and Kamens, 2001; Kleindienst et al., 2004). The carbon balance is poorly constrained; generally, only about $50 \%$ of the reacted carbon has been identified as products (Calvert et al., 2002).

SOA formation from individual precursors is typically studied in laboratory chamber experiments. Aerosol yields from the photooxidation of aromatic hydrocarbons have been shown to be highly sensitive to the $\mathrm{NO}_{\mathrm{x}}$ level (Hurley et al., 2001; Johnson et al., 2004, 2005; Song et al., 2005); generally, a higher SOA yield is observed under low- $\mathrm{NO}_{\mathrm{x}}$ conditions. This general dependence of SOA formation on the $\mathrm{NO}_{\mathrm{x}}$ level has been proposed to be the result of differences in concentrations of different oxidants $\left(\mathrm{OH}, \mathrm{O}_{3}\right.$, and $\left.\mathrm{NO}_{3}\right)$ (Hurley et al., 2001), or in changes in peroxy radical chemistry (Hatakeyama et al., 1991; Johnson et al., 2004, 2005; Presto et al., 2005; Kroll et al., 2006). In addition, particlephase reactions have been found to be important processes in SOA formation (Kalberer et al., 2004; Gao et al., 2004a, b;

Published by Copernicus Publications on behalf of the European Geosciences Union. 
Tolocka et al., 2004), and the presence of sulfuric acid seed has been shown to lead to increased SOA yields in a number of systems (Jang et al., 2002; Iinuma et al., 2004; Gao et al., 2004a, b; Edney et al., 2005). Odum et al. (1996, 1997a, b) performed an extensive study on aromatic SOA formation. In light of the recent findings on the $\mathrm{NO}_{\mathrm{x}}$ dependence and effect of seed aerosol acidity on SOA yields, it is important that SOA formation from aromatics be restudied to establish fully the $\mathrm{NO}_{\mathrm{x}}$ dependence and effect of particle acidity on SOA formation.

Most chamber experiments of SOA formation by aromatics involve the irradiation of aromatic/ $/ \mathrm{NO}_{\mathrm{x}}$ mixtures (Izumi and Fukuyama, 1990; Odum et al., 1996, 1997a, b; Hurley et al., 2001; Johnson et al., 2004; Song et al., 2005). In these classical photooxidation experiments, the $\mathrm{NO}$ and $\mathrm{NO}_{2}$ concentrations (hence $\mathrm{NO} / \mathrm{NO}_{2}$ ratio) constantly change, making it difficult to isolate the effect of $\mathrm{NO}_{\mathrm{x}}$ on $\mathrm{SOA}$ formation. For example, the decreasing $\mathrm{NO}$ concentration over the course of the experiment may lead to a switch from "high- $\mathrm{NO}_{\mathrm{x}}$ " conditions to "low- $\mathrm{NO}_{\mathrm{x}}$ " conditions for the peroxy radical chemistry (Johnson et al., 2004). Another potential complication in interpreting SOA data is that a delay in aerosol formation from the onset of photooxidation has been frequently observed in aromatic systems; in particular, aerosol does not form until the concentration of NO approaches zero. When extrapolating to urban areas where the $\mathrm{NO}_{\mathrm{x}}$ level is usually high, this would suggest that aromatics (and other hydrocarbons) do not produce SOA in the atmosphere. The observation that SOA does not form until [NO] approaches zero is not universal, however; in a study of toluene photooxidation by Stroud et al. (2004), aerosol growth is observed even at NO concentrations of $1-3 \mathrm{ppm}$. Thus the $\mathrm{NO}_{\mathrm{x}}$ dependence of SOA yields, which is a crucial parameter for atmospheric modeling, is very poorly understood.

In this work, SOA formation from the photooxidation of $m$-xylene, toluene, and benzene is investigated. A main goal of this study is to establish the $\mathrm{NO}_{\mathrm{x}}$ dependence of SOA formation for these aromatic hydrocarbons. In the experiments, SOA formation under two $\mathrm{NO}_{\mathrm{x}}$ conditions is studied: (1) high- $\mathrm{NO}_{\mathrm{x}}$ experiments in which $\mathrm{HONO}$ is used as the $\mathrm{OH}$ precursor and the $\mathrm{NO}_{\mathrm{x}}$ level at the inception of photooxidation is $\sim 1 \mathrm{ppm}$; and (2) low- $\mathrm{NO}_{\mathrm{x}}$ experiments in which $\mathrm{H}_{2} \mathrm{O}_{2}$ is used as the $\mathrm{OH}$ precursor and no $\mathrm{NO}_{\mathrm{x}}$ is introduced into the chambers. The background $\mathrm{NO}_{\mathrm{x}}$ concentration is $<1 \mathrm{ppb}$, which is within the uncertainty of the $\mathrm{NO}_{\mathrm{x}}$ monitor. By performing experiments at these extreme $\mathrm{NO}_{\mathrm{x}}$ limits, the oxidation conditions (initiating oxidant and fate of peroxy radicals) can be maintained relatively constant over the course of the experiment, allowing for the evaluation of the effect of $\mathrm{NO}_{\mathrm{x}}$ level on SOA formation. Additionally, the effect of seed aerosol acidity on SOA formation is studied under both high- and low- $\mathrm{NO}_{\mathrm{x}}$ conditions. The SOA yield parameters obtained at the two $\mathrm{NO}_{\mathrm{x}}$ limits allow one to parameterize the $\mathrm{NO}_{\mathrm{x}}$ dependence of $\mathrm{SOA}$ formation for use in atmospheric models (Presto et al., 2006).

\section{Experimental section}

Experiments are performed in Caltech's indoor, dual $28 \mathrm{~m}^{3}$ Teflon environmental chambers. Details of the facilities have been given elsewhere (Cocker et al., 2001; Keywood et al., 2004). Before each experiment, the chambers are flushed continuously with dry purified air for $\sim 24 \mathrm{~h}$. Each chamber has a dedicated Differential Mobility Analyzer (DMA, TSI model 3081) coupled with a condensation nucleus counter (TSI model 3760) for measuring aerosol size distribution, number concentration, and volume concentration. All aerosol growth data are corrected for wall loss, in which size-dependent coefficients determined from inert particle wall loss experiments are applied to the aerosol volume data (Keywood et al., 2004). Generally, the wall loss coefficients range from $10^{-4}$ to $10^{-2}$ particles $\mathrm{min}^{-1}$. Temperature, relative humidity $(\mathrm{RH}), \mathrm{O}_{3}, \mathrm{NO}$, and $\mathrm{NO}_{\mathrm{x}}$ are continuously monitored. Half of the available black lights are used in the experiments. The initial temperature of the chamber is $\sim 20^{\circ} \mathrm{C}$. Heating from the lights leads to a temperature increase of approximately $5^{\circ} \mathrm{C}$ inside the chamber over the course of the experiment. The analytical instruments are located outside the chamber enclosure and are at the temperature of the surrounding room $\left(\sim 20-22^{\circ} \mathrm{C}\right)$. The air may cool slightly as it is sampled from the chamber into the instruments, and the measured aerosol likely corresponds to the gas-particle partitioning at the temperature of the instruments rather than the chamber enclosure. Such small temperature differences are unlikely to affect results significantly.

Seed particles are introduced into the chamber to act as a substrate onto which the gas-phase products may condense. In an earlier work, we have shown that without seed particles, there is an "induction period" in which hydrocarbon is reacted but no aerosol is formed, which has the effect of biasing SOA yield measurements low (Kroll et al., 2007). Therefore, for all experiments in this study seed particles are used to eliminate this effect. Seed particles are generated by atomizing an aqueous solution with a constant-rate atomizer. The nonacid seed consists of $0.015 \mathrm{M}\left(\mathrm{NH}_{4}\right)_{2} \mathrm{SO}_{4}$, while the acidic seed contains a mixture of $0.015 \mathrm{M}\left(\mathrm{NH}_{4}\right)_{2} \mathrm{SO}_{4}$ and $0.015 \mathrm{M} \mathrm{H}_{2} \mathrm{SO}_{4}$. Since all experiments are performed at $\mathrm{RH} \sim 5 \%$, which is lower than the crystallization RH (35\%) of ammonium sulfate, the nonacid seed is likely a solid (Seinfeld and Pandis, 2006). The initial particle number concentration is about 30000 particles $\mathrm{cm}^{-3}$, with a geometric mean diameter of about $50 \mathrm{~nm}$. Initial aerosol seed volume is about $15 \mu \mathrm{m}^{3} \mathrm{~cm}^{-3}$. After introduction of the seed aerosol, a known volume of the parent hydrocarbon is injected into a glass bulb, and introduced into the chambers by an air stream. The concentration (mixing ratio) of the parent hydrocarbon is monitored with a Hewlett Packard gas chromatograph (model 5890) with flame ionization detection (GC-FID).

In most of the high- $\mathrm{NO}_{\mathrm{x}}$ experiments nitrous acid (HONO) serves as the $\mathrm{OH}$ precursor. It is introduced into the 
Table 1. Aromatic hydrocarbons studied.

\begin{tabular}{|c|c|c|c|}
\hline $\begin{array}{c}\text { Parent } \\
\text { Hydrocarbon }\end{array}$ & Structure & Formula (MW) & $k_{\mathrm{OH}}{ }^{\mathrm{a}}\left(\mathrm{cm}^{3} \operatorname{molec}^{-1} \mathrm{~s}^{-1}\right)$ \\
\hline$m$-xylene & & $\mathrm{C}_{8} \mathrm{H}_{10}(106)$ & $2.31 \times 10^{-11}$ \\
\hline toluene & & $\mathrm{C}_{7} \mathrm{H}_{8}(92)$ & $5.63 \times 10^{-12}$ \\
\hline benzene & & $\mathrm{C}_{6} \mathrm{H}_{6}(78)$ & $1.22 \times 10^{-12}$ \\
\hline
\end{tabular}

a: Rate constants were obtained from Calvert et al. (2002).

Table 2. Initial conditions and data for high- $\mathrm{NO}_{\mathrm{x}}(\mathrm{HONO})$ experiments.

\begin{tabular}{llllllllll}
\hline $\begin{array}{l}\text { Expt. } \\
\text { No. }\end{array}$ & $\begin{array}{l}\text { Parent } \\
\text { Hydrocarbon }\end{array}$ & $\begin{array}{l}\mathrm{T} \\
\mathrm{K})\end{array}$ & $\begin{array}{l}\mathrm{RH} \\
(\%)\end{array}$ & $\begin{array}{l}\mathrm{NO} \\
(\mathrm{ppb})\end{array}$ & $\begin{array}{l}\mathrm{NO}_{2} \\
(\mathrm{ppb})\end{array}$ & Seed & $\begin{array}{l}\Delta \mathrm{HC} \\
(\mathrm{ppb})\end{array}$ & $\begin{array}{l}\Delta M_{O} \\
\left(\mu \mathrm{g} / \mathrm{m}^{3}\right)\end{array}$ & $\begin{array}{l}\text { SOA Yield } \\
(\%)^{\mathrm{a}}\end{array}$ \\
\hline 1 & $m$-xylene & 297 & 5.5 & 470 & 473 & $\left(\mathrm{NH}_{4}\right)_{2} \mathrm{SO}_{4}$ & 70.9 & $18.2 \pm 1.8$ & $5.9 \pm 0.4$ \\
2 & $m$-xylene & 298 & 5.7 & 451 & 494 & $\left(\mathrm{NH}_{4}\right)_{2} \mathrm{SO}_{4}$ & 28.1 & $4.3 \pm 1.2$ & $3.5 \pm 0.7$ \\
3 & $m$-xylene & 298 & 5.9 & 432 & 511 & $\left(\mathrm{NH}_{4}\right)_{2} \mathrm{SO}_{4}$ & 132.5 & $46.4 \pm 3.7$ & $8.0 \pm 0.3$ \\
4 & $m$-xylene & 297 & 5.1 & 431 & 514 & $\left(\mathrm{NH}_{4}\right)_{2} \mathrm{SO}_{4}$ & 106.1 & $36.7 \pm 2.8$ & $8.0 \pm 0.2$ \\
5 & toluene & 298 & 3.8 & 421 & 524 & $\left(\mathrm{NH}_{4}\right)_{2} \mathrm{SO}_{4}$ & 30.1 & $9.1 \pm 1.3$ & $8.0 \pm 0.7$ \\
6 & toluene & 298 & 4.3 & 414 & 532 & $\left(\mathrm{NH}_{4}\right)_{2} \mathrm{SO}_{4}$ & 56.7 & $23.8 \pm 2.2$ & $11.1 \pm 0.4$ \\
7 & toluene & 298 & 4.9 & 388 & 559 & $\left(\mathrm{NH}_{4}\right)_{2} \mathrm{SO}_{4}$ & 80.2 & $38.7 \pm 3.3$ & $12.8 \pm 0.4$ \\
8 & toluene & 298 & 4.4 & 373 & 568 & $\left(\mathrm{NH}_{4}\right)_{2} \mathrm{SO}_{4}$ & 50.7 & $20.9 \pm 1.9$ & $10.9 \pm 0.5$ \\
9 & benzene & 297 & 5.2 & 83 & 86 & $\left(\mathrm{NH}_{4}\right)_{2} \mathrm{SO}_{4}$ & 39.4 & $35.4 \pm 2.7^{\mathrm{b}}$ & $28.1 \pm 0.9$ \\
\hline
\end{tabular}

a: Stated uncertainties $(1 \sigma)$ are from scatter in particle volume measurements.

$\mathrm{b}$ : Assuming an SOA density of $1.4 \mathrm{~g} \mathrm{~cm}^{-3}$.

chamber after injection of the seed aerosol and parent hydrocarbon. HONO is prepared by dropwise addition of $15 \mathrm{~mL}$ of $1 \% \mathrm{NaNO}_{2}$ into $30 \mathrm{~mL}$ of $10 \% \mathrm{H}_{2} \mathrm{SO}_{4}$ in a glass bulb. The bulb is then attached to the chamber and a stream of dry air is passed through the bulb into the chamber. $\mathrm{NO}$ and $\mathrm{NO}_{2}$, formed as side products in the preparation of $\mathrm{HONO}$, are also introduced into the chamber, and are measured by a commercial $\mathrm{NO}_{\mathrm{x}}$ monitor (Horiba APNA-360, Irvine, CA). Additional NO from a 500 ppm gas cylinder (Scott Marrin, Inc.) is introduced into the chamber after the addition of HONO to achieve a total $\mathrm{NO}_{\mathrm{x}}$ level in the chamber of about $1 \mathrm{ppm}$ (upper limit of the $\mathrm{NO}_{\mathrm{x}}$ monitor). In some high- $\mathrm{NO}_{\mathrm{x}}$ experiments, only $\mathrm{NO}$ and $\mathrm{NO}_{2}$ (from gas cylinders) are added to the chamber. To differentiate these experiments from the high- $\mathrm{NO}_{\mathrm{x}}$ experiments in which $\mathrm{HONO}$ is used as the $\mathrm{OH}$ precursor, we refer to these experiments as classical photooxidation experiments. The majority of the high- $\mathrm{NO}_{\mathrm{x}}$ experi- ments in this study are performed with HONO; only a few classical photooxidation experiments are performed for comparison purposes.

For low- $\mathrm{NO}_{\mathrm{x}}$ experiments, $\mathrm{H}_{2} \mathrm{O}_{2}$ is used as the $\mathrm{OH}$ precursor. The background $\mathrm{NO}_{\mathrm{x}}$ level in the chamber during the experiment is $<1 \mathrm{ppb}$. $\mathrm{H}_{2} \mathrm{O}_{2}$ is introduced into the chamber (prior to introduction of seed particles and parent hydrocarbon) by bubbling air through a $50 \% \mathrm{H}_{2} \mathrm{O}_{2}$ solution for $2.5 \mathrm{~h}$ at $5 \mathrm{~L} / \mathrm{min}$. The air stream then passes through a particle filter to remove any droplets. The concentration of $\mathrm{H}_{2} \mathrm{O}_{2}$ in the chamber is not measured; based on the rate of hydrocarbon decay and literature values of $\sigma_{\mathrm{H} 2 \mathrm{O} 2}$ and $k_{\mathrm{OH}+\mathrm{H} 2 \mathrm{O} 2}$, we estimate $\left[\mathrm{H}_{2} \mathrm{O}_{2}\right]$ to be $\sim 3-5 \mathrm{ppm}$ (Kroll et al., 2006).

Once the seed, parent hydrocarbon, and $\mathrm{NO}_{\mathrm{x}}$ concentrations stabilize, reaction is initiated by irradiating the chamber with blacklights. Output from the lights is between 300 and $400 \mathrm{~nm}$, with a maximum at $354 \mathrm{~nm}$. At these wavelengths 
Table 3. Initial conditions and data for low- $\mathrm{NO}_{\mathrm{x}}\left(\mathrm{H}_{2} \mathrm{O}_{2}\right)$ experiments.

\begin{tabular}{llllllll}
\hline Expt. No. & $\begin{array}{l}\text { Parent } \\
\text { Hydrocarbon }\end{array}$ & $\begin{array}{l}\mathrm{T} \\
(\mathrm{K})\end{array}$ & $\begin{array}{l}\mathrm{RH} \\
(\%)\end{array}$ & Seed & $\begin{array}{l}\Delta \mathrm{HC} \\
(\mathrm{ppb})\end{array}$ & $\begin{array}{l}\Delta M_{O} \\
\left(\mu \mathrm{g} / \mathrm{m}^{3}\right)\end{array}$ & $\begin{array}{l}\text { SOA Yield } \\
(\%)^{\mathrm{a}}\end{array}$ \\
\hline 1 & $m$-xylene & 298 & 5.1 & $\left(\mathrm{NH}_{4}\right)_{2} \mathrm{SO}_{4}$ & 32.5 & $53.0 \pm 4.2$ & $37.7 \pm 0.8$ \\
2 & $m$-xylene & 298 & 5.2 & $\left(\mathrm{NH}_{4}\right)_{2} \mathrm{SO}_{4}$ & 16.1 & $24.6 \pm 2.2$ & $35.2 \pm 1.8$ \\
3 & $m$-xylene & 298 & 5.1 & $\left(\mathrm{NH}_{4}\right)_{2} \mathrm{SO}_{4}$ & 8.0 & $12.8 \pm 1.7$ & $36.7 \pm 2.6$ \\
4 & $m$-xylene & 297 & 6.2 & $\left(\mathrm{NH}_{4}\right)_{2} \mathrm{SO}_{4}$ & 26.1 & $40.5 \pm 3.4$ & $35.7 \pm 1.0$ \\
5 & toluene & 297 & 6.8 & $\left(\mathrm{NH}_{4}\right)_{2} \mathrm{SO}_{4}$ & 32.1 & $37.4 \pm 2.8$ & $30.8 \pm 1.7$ \\
6 & toluene & 297 & 6.2 & $\left(\mathrm{NH}_{4}\right)_{2} \mathrm{SO}_{4}$ & 63.9 & $73.1 \pm 5.6$ & $30.2 \pm 0.7$ \\
7 & toluene & 298 & 5.2 & $\left(\mathrm{NH}_{4}\right)_{2} \mathrm{SO}_{4}$ & 10.0 & $11.5 \pm 1.6$ & $30.4 \pm 4.1$ \\
8 & toluene & 298 & 5.9 & $\left(\mathrm{NH}_{4}\right)_{2} \mathrm{SO}_{4}$ & 23.8 & $26.7 \pm 2.5$ & $29.8 \pm 1.6$ \\
9 & benzene & 298 & 6.6 & $\left(\mathrm{NH}_{4}\right)_{2} \mathrm{SO}_{4}$ & 64.7 & $76.4 \pm 5.8 \mathrm{~b}$ & $36.9 \pm 0.9$ \\
\hline
\end{tabular}

a: Stated uncertainties $(1 \sigma)$ are from scatter in particle volume measurements.

b: Assuming an SOA density of $1.4 \mathrm{~g} \mathrm{~cm}^{-3}$.

Table 4. Initial conditions and data for acid/nonacid experiments.

\begin{tabular}{lllllllll}
\hline $\begin{array}{l}\text { Expt. } \\
\text { No. }\end{array}$ & Parent & $\mathrm{T}$ & $\begin{array}{l}\mathrm{RH} \\
(\%)\end{array}$ & $\begin{array}{l}\mathrm{NO}_{\mathrm{x}} \\
\text { Condition }\end{array}$ & Seed & $\begin{array}{l}\Delta \mathrm{HC} \\
(\mathrm{ppb})\end{array}$ & $\begin{array}{l}\Delta M_{O} \\
\left(\mu \mathrm{g} / \mathrm{m}^{3}\right)\end{array}$ & $\begin{array}{l}\text { SOA Yield } \\
(\%)^{\mathrm{b}}\end{array}$ \\
\hline 1 & $m$-xylene & 297 & 4.3 & Low $\mathrm{NO}_{\mathrm{x}}$ & $\left(\mathrm{NH}_{4}\right)_{2} \mathrm{SO}_{4}$ & 60.2 & $101.3 \pm 7.8$ & $38.6 \pm 0.5$ \\
2 & $m$-xylene & 297 & 4.5 & Low $\mathrm{NO}_{\mathrm{x}}$ & $\left(\mathrm{NH}_{4}\right)_{2} \mathrm{SO}_{4}+\mathrm{H}_{2} \mathrm{SO}_{4}$ & 58.8 & $103.5 \pm 8.0$ & $40.4 \pm 0.6$ \\
3 & $m$-xylene & 297 & 5.0 & $\mathrm{High} \mathrm{NO}_{\mathrm{x}}$ & $\left(\mathrm{NH}_{4}\right)_{2} \mathrm{SO}_{4}$ & 68.9 & $78.9 \pm 5.6^{\mathrm{c}}$ & $26.3 \pm 0.5$ \\
4 & $m$-xylene & 298 & 4.2 & High $\mathrm{NO}_{\mathrm{x}}$ & $\left(\mathrm{NH}_{4}\right)_{2} \mathrm{SO}_{4}+\mathrm{H}_{2} \mathrm{SO}_{4}$ & 68.5 & $78.3 \pm 5.4^{\mathrm{c}}$ & $26.3 \pm 0.4$ \\
5 & toluene & 298 & 5.9 & Low $\mathrm{NO}_{\mathrm{x}}$ & $\left(\mathrm{NH}_{4}\right)_{2} \mathrm{SO}_{4}$ & 37.9 & $41.0 \pm 3.0$ & $28.7 \pm 0.6$ \\
6 & toluene & 299 & 4.6 & Low $\mathrm{NO}_{\mathrm{x}}$ & $\left(\mathrm{NH}_{4}\right)_{2} \mathrm{SO}_{4}+\mathrm{H}_{2} \mathrm{SO}_{4}$ & 38.9 & $43.2 \pm 3.2$ & $29.5 \pm 0.7$ \\
7 & toluene & 296 & 4.9 & $\mathrm{High} \mathrm{NO}_{\mathrm{x}}$ & $\left(\mathrm{NH}_{4}\right)_{2} \mathrm{SO}_{4}$ & 60.0 & $43.8 \pm 3.6^{\mathrm{c}}$ & $19.3 \pm 0.4$ \\
8 & toluene & 298 & 4.9 & High $\mathrm{NO}_{\mathrm{x}}$ & $\left(\mathrm{NH}_{4}\right)_{2} \mathrm{SO}_{4}+\mathrm{H}_{2} \mathrm{SO}_{4}$ & 58.2 & $38.3 \pm 3.2^{\mathrm{c}}$ & $17.4 \pm 0.5$ \\
\hline
\end{tabular}

a: Low $\mathrm{NO}_{\mathrm{x}}\left(\mathrm{H}_{2} \mathrm{O}_{2}\right.$ only); high $\mathrm{NO}_{\mathrm{x}}\left(\mathrm{H}_{2} \mathrm{O}_{2}+\right.$ about 100 ppb $\mathrm{NO}$ added $)$.

$\mathrm{b}$ : Stated uncertainties $(1 \sigma)$ are from scatter in particle volume measurements.

c: Assuming SOA densities are the same as those determined for HONO experiments (see Table 5).

Table 5. Estimated effective SOA densities.

\begin{tabular}{lll}
\hline $\begin{array}{l}\text { Parent } \\
\text { Hydrocarbon }\end{array}$ & $\mathrm{NO}_{\mathrm{x}}$ Condition & $\begin{array}{l}\text { Effective } \\
\text { Density }\left(\mathrm{g} \mathrm{cm}^{-3}\right)^{\mathrm{a}}\end{array}$ \\
\hline m-xylene & Low $\mathrm{NO}_{\mathrm{x}}$ & $1.33 \pm 0.10$ \\
m-xylene & ${\text { High } \mathrm{NO}_{\mathrm{x}}}_{\text {tuene }}^{\text {Low } \mathrm{NO}_{\mathrm{x}}}$ & $1.48 \pm 0.10$ \\
toluene & ${\text { High } \mathrm{NO}_{\mathrm{x}}}$ & $1.45 \pm 0.10$ \\
\hline
\end{tabular}

a: Stated uncertainties $(1 \sigma)$ are from repeated measurements of ammonium sulfate seed densities.

HONO efficiently photolyzes to $\mathrm{OH}$ and NO. By contrast $\mathrm{H}_{2} \mathrm{O}_{2}$ absorbs only weakly in this wavelength range, requiring the use of ppm concentrations of $\mathrm{H}_{2} \mathrm{O}_{2}$ to achieve reasonable levels of $\mathrm{OH}$.

The parent aromatics studied (shown in Table 1) and their stated purities are as follows: $m$-xylene (Aldrich, anhydrous, 99+\%), toluene (Aldrich, anhydrous, 99.8\%), and benzene (Aldrich, anhydrous, 99.8\%). Experimental conditions and results for high- $\mathrm{NO}_{\mathrm{x}}$ and low- $\mathrm{NO}_{\mathrm{x}}$ experiments are given in Tables 2 and 3, while those for studying the effect of seed acidity on SOA growth are given in Table 4. In calculating SOA yield (defined as the ratio of the mass of organic aerosol formed to the mass of parent hydrocarbon reacted), knowledge of the SOA density is required. By comparing volume distributions from the DMA and mass distributions from an Aerodyne quadrupole Aerosol Mass Spectrometer (AMS), the effective densities for the SOA formed can be estimated (Bahreini et al., 2005). The estimated densities of the SOA formed from different systems are given in Table 5. 


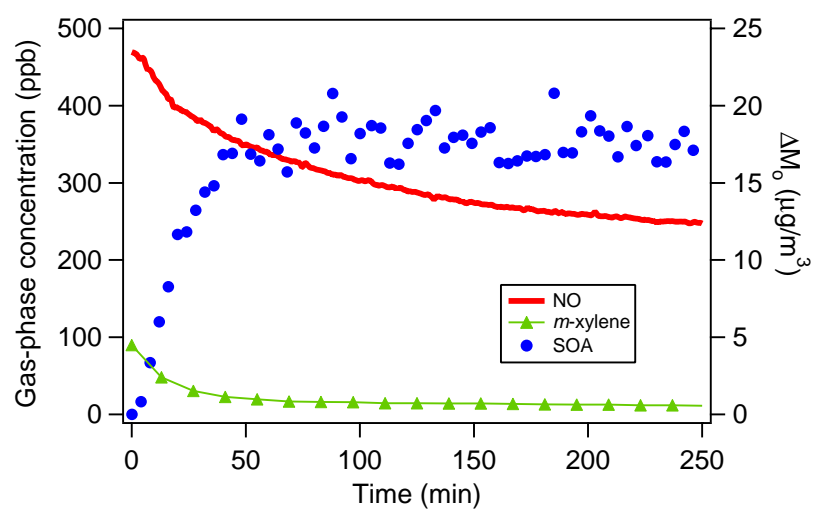

Fig. 1. Typical reaction profile of a high- $\mathrm{NO}_{\mathrm{x}}$ experiment in which $\mathrm{HONO}$ is used as the $\mathrm{OH}$ precursor (initial conditions: $89.3 \mathrm{ppb}$ of $m$-xylene, $470 \mathrm{ppb} \mathrm{NO}$, and $473 \mathrm{ppb} \mathrm{NO}_{2}$ ).

\section{Results}

\subsection{High- $\mathrm{NO}_{\mathrm{x}}$ conditions}

Figure 1 shows a typical reaction profile under high- $\mathrm{NO}_{\mathrm{x}}$ conditions in which HONO is used as the $\mathrm{OH}$ precursor. In this experiment, $89 \mathrm{ppb}$ of $m$-xylene is reacted, and initial $\mathrm{NO}$ and $\mathrm{NO}_{2}$ concentrations are $470 \mathrm{ppb}$ and $473 \mathrm{ppb}$, respectively. The efficient photolysis of $\mathrm{HONO}$ generates high concentrations of $\mathrm{OH}\left(\sim 3 \times 10^{7}\right.$ molecules $\mathrm{cm}^{-3}$ initially $)$, leading to a rapid hydrocarbon decay. This decay slows down after $\sim 1 \mathrm{~h}$, suggesting that the HONO is consumed and $\mathrm{OH}$ radicals are instead generated through recycling via $\mathrm{NO}_{\mathrm{x}} / \mathrm{HO}_{\mathrm{x}}$ chemistry. Aerosol growth occurs essentially immediately, even when [NO] is high (100's of ppb). With the high $\mathrm{NO}$ concentration, formation of ozone (and hence $\mathrm{NO}_{3}$ radicals) is suppressed.

Concentration (mixing ratio) profiles from two classical photooxidation experiments with different initial $\mathrm{NO}_{\mathrm{x}}$ concentrations are shown in Fig. 2. Figure 2a shows the reaction profile from the photooxidation of $101.6 \mathrm{ppb} m$-xylene, with initial $\mathrm{NO}$ and $\mathrm{NO}_{2}$ concentrations of $97 \mathrm{ppb}$ and $26 \mathrm{ppb}$, respectively. The hydroxyl radical source in classical photooxidation experiments is likely from the photolysis of $\mathrm{HONO}$, which is formed from the heterogeneous reaction of $\mathrm{NO}_{2}$ on the chamber wall. The $m$-xylene-OH reaction leads to formation of $\mathrm{RO}_{2}$ radicals, which react with $\mathrm{NO}$ rapidly, converting $\mathrm{NO}$ to $\mathrm{NO}_{2}$. Ozone is formed from the photolysis of $\mathrm{NO}_{2}$, with its concentration increasing rapidly when [NO] falls below $\sim 50 \mathrm{ppb}$. Only when the NO concentration approaches zero does aerosol growth begin, consistent with other classical photooxidation experiments (Izumi and Fukuyama, 1990; Hurley et al., 2001; Johnson et al., 2004; Martin-Revíejo and Wirtz, 2005; Song et al., 2005). The difference between high- $\mathrm{NO}_{\mathrm{x}}$ experiments and classical photooxidation experiments will be discussed in Sect. 4.2. Figure $2 b$ shows the reaction profile for the photooxidation of

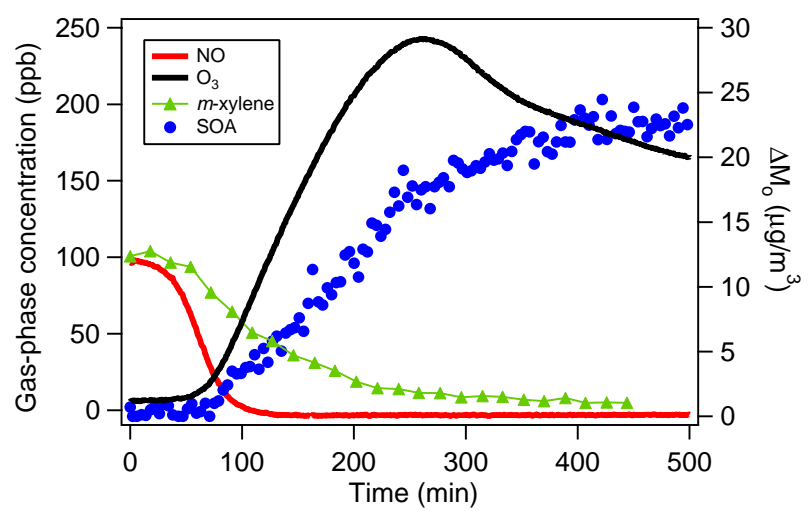

Fig. 2a. Reaction profile of a typical classical photooxidation experiment (initial conditions: $101.6 \mathrm{ppb} m$-xylene, $97 \mathrm{ppb} \mathrm{NO}$, and $26 \mathrm{ppb} \mathrm{NO}_{2}$ ).

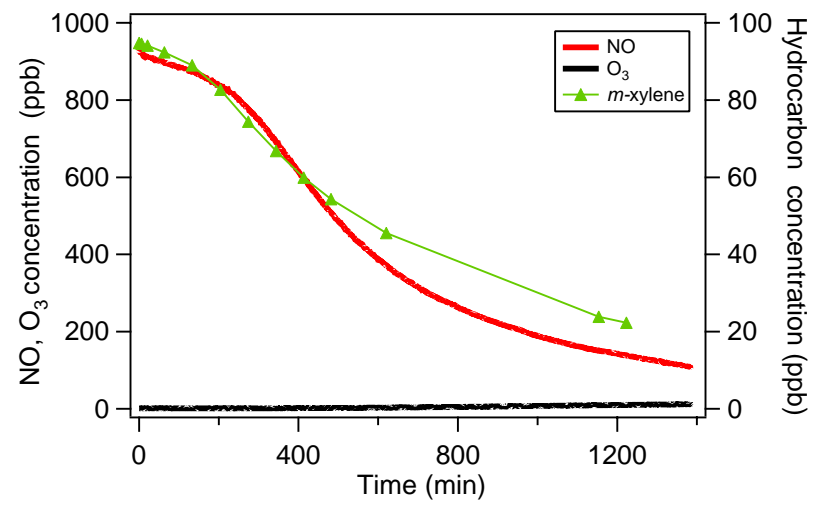

Fig. 2b. Reaction profile of a classical photooxidation experiment in the presence of $\sim 1 \mathrm{ppm} \mathrm{NO}$ (initial conditions: $94.8 \mathrm{ppb} \mathrm{m}$ xylene, $878 \mathrm{ppb} \mathrm{NO}$, and $65 \mathrm{ppb} \mathrm{NO}_{2}$ ). A negligible amount of ozone is formed during the experiment, and no SOA is formed.

$94.8 \mathrm{ppb} m$-xylene, with initial $\mathrm{NO}$ and $\mathrm{NO}_{2}$ concentrations of $878 \mathrm{ppb}$ and $65 \mathrm{ppb}$, respectively. The NO concentration decreases over the course of the experiment, but does not fall below $100 \mathrm{ppb}$, even after $20 \mathrm{~h}$. A negligible amount of ozone is formed during the experiment, and no SOA is formed.

For $m$-xylene and toluene, a series of high- $\mathrm{NO}_{\mathrm{x}}$ experiments (HONO experiments) with varying initial hydrocarbon concentrations are carried out. The time-dependent "growth curves" (organic aerosol $\Delta M_{o}$ as a function of hydrocarbon reacted $\triangle \mathrm{HC}$ ) over the course of the experiment, for four $m$-xylene experiments, with initial hydrocarbon concentrations ranging from 42 to $172 \mathrm{ppb}$, are shown in Fig. 3. In these experiments, $67-79 \%$ of the initial $m$-xylene is consumed. Most of the parent hydrocarbon is consumed in the first hour and the maximum aerosol yield is reached. After that hydrocarbon continues to decay slowly and there is little or no SOA growth, as a result the aerosol yield decreases. Only SOA growth data up to the maximum aerosol yield are shown. 


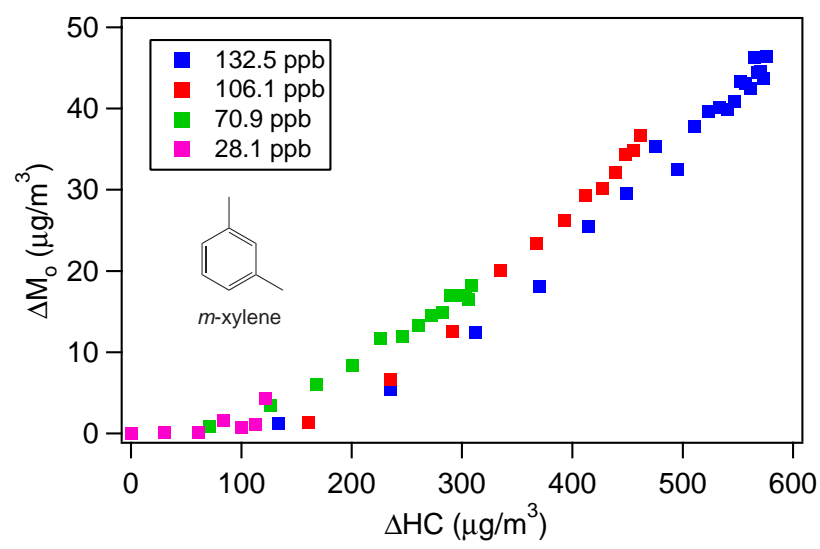

Fig. 3. Time-dependent growth curves for $m$-xylene photooxidation under high- $\mathrm{NO}_{\mathrm{x}}$ conditions. The concentrations in the legend refer to the amount of $m$-xylene reacted in each experiment.

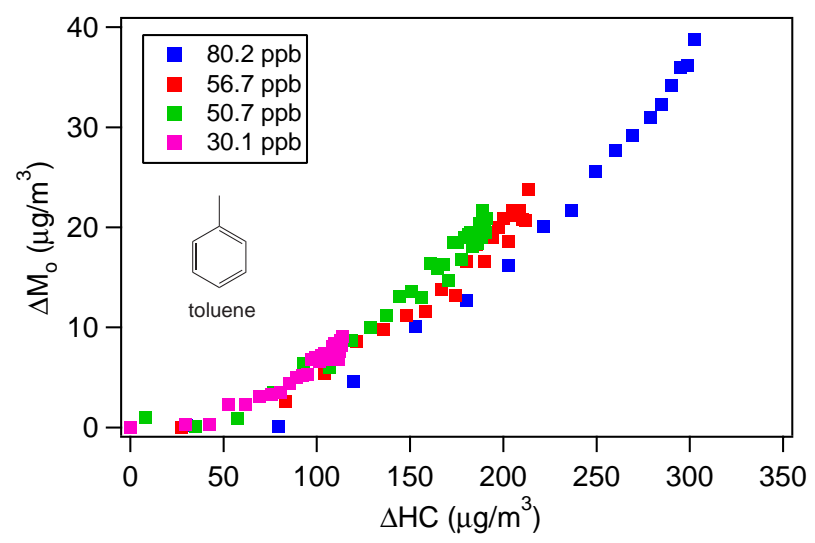

Fig. 4. Time-dependent growth curves for toluene photooxidation under high- $\mathrm{NO}_{\mathrm{x}}$ conditions. The concentrations in the legend refer to the amount of toluene reacted in each experiment.

The time-dependent growth curves for four toluene experiments are shown in Fig. 4. The initial toluene concentration ranges from 88 to $270 \mathrm{ppb}$. Since the toluene-OH reaction rate constant is $\sim 4$ times lower than that of $m$-xylene$\mathrm{OH}$, more initial toluene is needed relative to $m$-xylene; only about $30-37 \%$ of the initial toluene injected is consumed at the point of maximum aerosol yield. Photooxidation of toluene under high- $\mathrm{NO}_{\mathrm{x}}$ conditions results in slightly more SOA growth than for $m$-xylene.

Because benzene reacts slowly with $\mathrm{OH}$ radicals $\left(k=1.22 \times 10^{-12} \mathrm{~cm}^{3}\right.$ molecule ${ }^{-1} \mathrm{~s}^{-1}$, Calvert et al., 2002), it is not feasible to carry out photooxidation experiments over a range of initial benzene concentrations unless high levels (ppm) of benzene are used. Thus only a single benzene photooxidation experiment at high $\mathrm{NO}_{\mathrm{x}}$ was carried out; at an initial benzene concentration of $337 \mathrm{ppb}$, only $12 \%$ is reacted at the point of maximum aerosol yield. The time-dependent

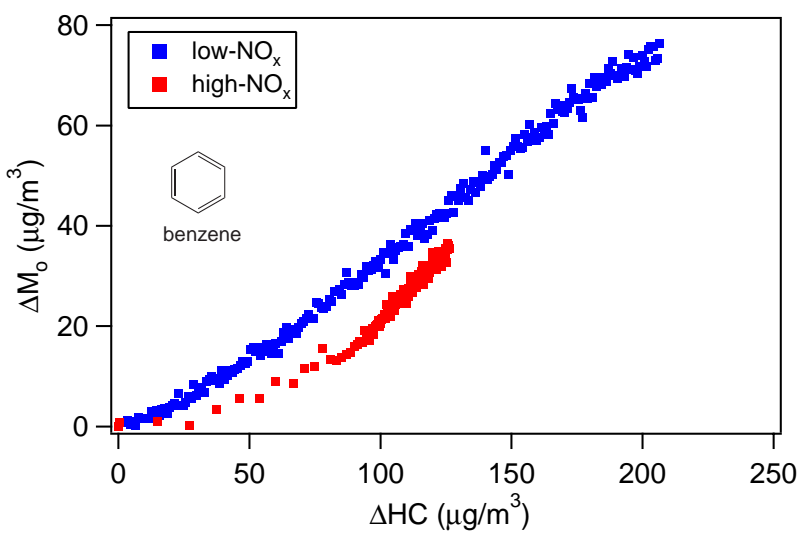

Fig. 5. Time-dependent growth curves for benzene photooxidation under high- and low- $\mathrm{NO}_{\mathrm{x}}$ conditions. Under high- $\mathrm{NO}_{\mathrm{x}}$ conditions, the initial benzene concentration is $337 \mathrm{ppb}$ (12\% reacted). Under low- $\mathrm{NO}_{\mathrm{x}}$ conditions, the initial benzene concentration is $395 \mathrm{ppb}$ (16\% reacted) and the system has a constant yield of $37 \%$.

growth curve from benzene under high- $\mathrm{NO}_{\mathrm{x}}$ conditions (as well as under low- $\mathrm{NO}_{\mathrm{x}}$ conditions) is shown in Fig. 5. Hydrocarbon decay slows down at $\Delta \mathrm{HC} \approx 90 \mu \mathrm{g} \mathrm{m}^{-3}$, suggesting that $\mathrm{HONO}$ is almost completely consumed. After that, $\mathrm{OH}$ is generated mainly via $\mathrm{NO}_{\mathrm{x}} / \mathrm{HO}_{\mathrm{x}}$ chemistry, and hydrocarbon decays at a slower rate resulting in the more closely spaced data points. The slower hydrocarbon oxidation rate after the consumption of HONO may affect the kinetics of SOA growth and contribute to the slight change in the shape of the growth curves.

\subsection{Low- $\mathrm{NO}_{\mathrm{x}}$ conditions}

Under low- $\mathrm{NO}_{\mathrm{x}}$ conditions, aerosol growth is observed immediately after initiation of irradiation. The parent hydrocarbon decays at a much slower rate than under high$\mathrm{NO}_{\mathrm{x}}$ conditions, due to the slow production of $\mathrm{OH}$ radicals by $\mathrm{H}_{2} \mathrm{O}_{2}$ photolysis and lack of $\mathrm{OH}$ regeneration by $\mathrm{NO}_{\mathrm{x}} / \mathrm{HO}_{\mathrm{x}}$ cycling. As $\mathrm{OH}$ radicals are continually produced, the $\mathrm{OH}$ concentration is constant throughout the experiment $\left(\sim 3 \times 10^{6}\right.$ molecules $\left.\mathrm{cm}^{-3}\right)$. Ozone formation of $\sim 10-15$ ppb is observed, possibly owing to residual material released from the chamber walls.

Time-dependent growth curves for four $m$-xylene low$\mathrm{NO}_{\mathrm{x}}$ experiments are shown in Fig. 6, with initial $m$-xylene concentrations ranging from 9 to $37 \mathrm{ppb}$. About $83-89 \%$ of the initial hydrocarbon injected is consumed at the point at which the SOA yield reaches its maximum. From Fig. 6 it is clear that the SOA yield from $m$-xylene photooxidation is constant under low- $\mathrm{NO}_{\mathrm{x}}$ conditions, at $36 \%$. Since the $m$ xylene SOA yield is much higher under low- $\mathrm{NO}_{\mathrm{x}}$ conditions, a smaller amount of initial parent hydrocarbon is needed to produce the same amount of SOA than under high- $\mathrm{NO}_{\mathrm{x}}$ conditions. Comparable time-dependent growth curves for four 


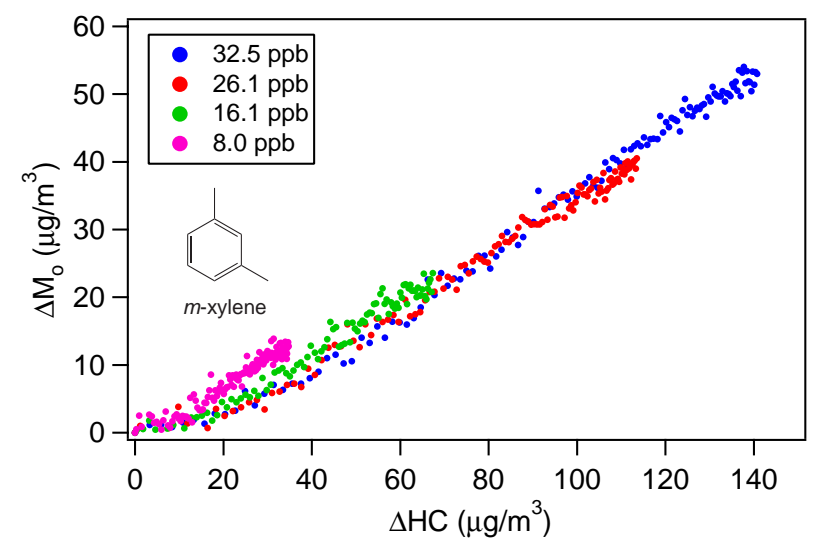

Fig. 6. Time-dependent growth curves for $m$-xylene photooxidation under low- $\mathrm{NO}_{\mathrm{x}}$ conditions. The concentrations in the legend refer to the amount of $m$-xylene reacted in each experiment. The system exhibits a constant yield of $36 \%$.

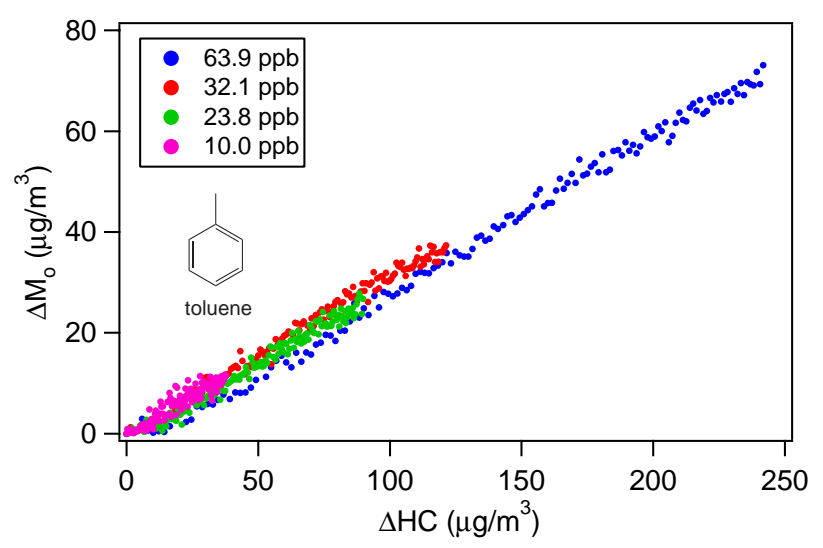

Fig. 7. Time-dependent growth curves for toluene photooxidation under low- $\mathrm{NO}_{\mathrm{x}}$ conditions. The concentrations in the legend refer to the amount of toluene reacted in each experiment. The system exhibits a constant yield of $30 \%$.

toluene low- $\mathrm{NO}_{\mathrm{x}}$ experiments are shown in Fig. 7. The initial toluene concentration ranges from 21 to $140 \mathrm{ppb}$. With the slower reactivity of toluene relative to $m$-xylene, only about $45-48 \%$ of the initial toluene is consumed. As with $m$ xylene, the aerosol yield (30\%) is substantially higher than under high- $\mathrm{NO}_{\mathrm{x}}$ conditions.

The time-dependent growth curve for benzene photooxidation is shown in Fig. 5. Similar to $m$-xylene and toluene, benzene photooxidation under low- $\mathrm{NO}_{\mathrm{x}}$ conditions results in a constant SOA yield (37\%).

\subsection{SOA yield parameters}

SOA yield has traditionally been described by a semiempirical model based on absorptive gas-particle partitioning of two semivolatile products (Odum et al., 1996, 1997a, b):

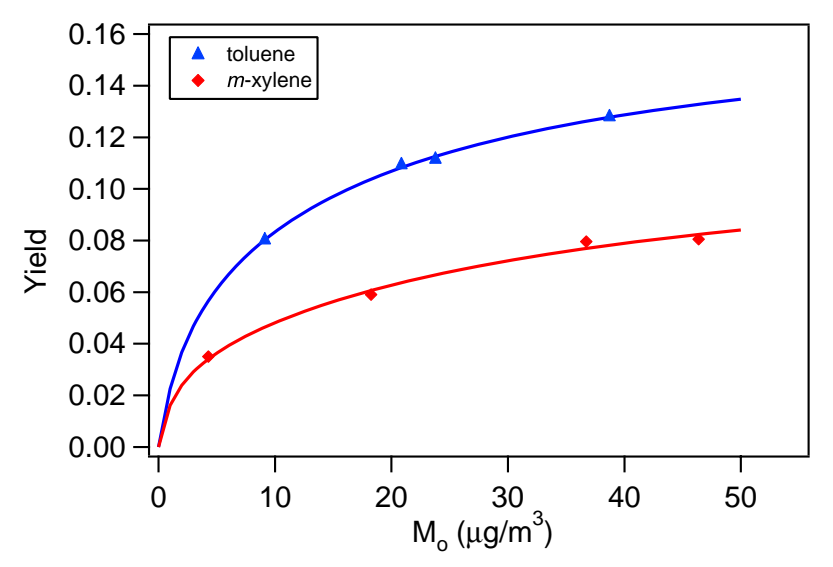

Fig. 8. Yield curves for toluene and $m$-xylene under high- $\mathrm{NO}_{\mathrm{x}}$ conditions. The parameters for fitting the yield curves are, toluene: $\alpha_{1}=0.058, K_{o m, 1}=0.430, \alpha_{2}=0.113$, and $K_{o m, 2}=0.047 ; m$-xylene: $\alpha_{1}=0.031, K_{o m, 1}=0.761, \alpha_{2}=0.090$, and $K_{o m, 2}=0.029$.

$Y=M_{o}\left[\frac{\alpha_{1} K_{o m, 1}}{1+K_{o m, 1} M_{o}}+\frac{\alpha_{2} K_{o m, 2}}{1+K_{o m, 2} M_{o}}\right]$

in which $Y$ is the aerosol yield, $M_{o}$ is the organic aerosol mass present (equal to $\Delta M_{o}$ in chamber experiments with no absorbing organic mass present initially), $\alpha_{i}$ is the massbased gas-phase stoichiometric fraction for semivolatile species $i$, and $K_{o m, i}$ is the gas-particle partitioning coefficient for species $i$. With this two-product model, Eq. (1) can be fit to experimental yield data to determine values for $\alpha_{i}$ and $K_{o m, i}$, and the resulting plot $\left(Y\right.$ versus $M_{o}$ ) is generally referred to as a "yield curve".

For $m$-xylene and toluene, the final SOA yield for each high- $\mathrm{NO}_{\mathrm{x}}(\mathrm{HONO})$ experiment is calculated, and the data are fitted to Eq. (1) to obtain the SOA yield parameters. The high- $\mathrm{NO}_{\mathrm{x}}$ yield curves for $m$-xylene and toluene are shown in Fig. 8. For all three aromatics ( $m$-xylene, toluene, and benzene), the low- $\mathrm{NO}_{\mathrm{x}}$ experiments result in a constant aerosol yield (the slope of the "growth curve"), implying the SOA formed can be represented by a single product with very low volatility. Under these conditions the yield curve is simply a horizontal line, and the constant yield corresponds to $\alpha_{1}$ in Eq. (1). SOA growth parameters for the three compounds under high- $\mathrm{NO}_{\mathrm{x}}$ and low- $\mathrm{NO}_{\mathrm{x}}$ conditions are summarized in Table 6.

\subsection{Acid/nonacid seed experiments}

Several $m$-xylene and toluene photooxidation experiments are performed in the presence of acid seed to study the effect of seed acidity on SOA growth. Growth curves for toluene photooxidation under acidic and nonacid conditions are shown in Fig. 9. Regardless of the $\mathrm{NO}_{\mathrm{x}}$ level, the timedependent growth curves from the acid and nonacid experiments are essentially indistinguishable. Therefore, there is 
Table 6. Aerosol yield parameters.

\begin{tabular}{|c|c|c|c|c|c|}
\hline $\begin{array}{l}\text { Parent } \\
\text { Hydrocarbon }\end{array}$ & $\mathrm{NO}_{\mathrm{x}}$ Condition & $\alpha_{1}$ & $\begin{array}{l}K_{o m, 1} \\
\left(\mathrm{~m}^{3} \mu \mathrm{g}^{-1}\right)\end{array}$ & $\alpha_{2}$ & $\begin{array}{l}K_{o m, 2} \\
\left(\mathrm{~m}^{3} \mu \mathrm{g}^{-1}\right)\end{array}$ \\
\hline$m$-xylene & Low $\mathrm{NO}_{\mathrm{X}}$ & 0.30 & N/A & N/A & N/A \\
\hline$m$-xylene & High $\mathrm{NO}_{\mathrm{x}}$ & 0.031 & 0.761 & 0.090 & 0.029 \\
\hline toluene & Low $\mathrm{NO}_{\mathrm{x}}$ & 0.36 & N/A & N/A & N/A \\
\hline toluene & $\operatorname{High} \mathrm{NO}_{\mathrm{x}}$ & 0.058 & 0.430 & 0.113 & 0.047 \\
\hline benzene & Low $\mathrm{NO}_{\mathrm{x}}$ & 0.37 & N/A & N/A & N/A \\
\hline benzene & $\operatorname{High} \mathrm{NO}_{\mathrm{x}}$ & 0.072 & 3.315 & 0.888 & 0.009 \\
\hline
\end{tabular}

N/A: not applicable

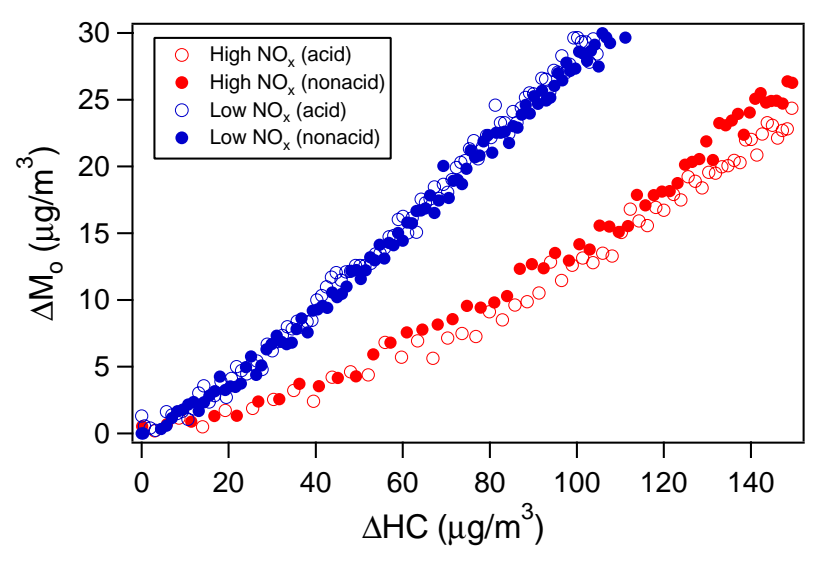

Fig. 9. Time-dependent growth curves for toluene photooxidation in the presence of neutral seed versus acidic seed.

no evidence that the presence of acidic seed enhances SOA growth in the photooxidation of toluene; similar results are observed for $m$-xylene.

\section{Discussion}

\subsection{Effect of $\mathrm{NO}_{\mathrm{x}}$ on $\mathrm{SOA}$ yields}

Experiments have been performed under two limiting $\mathrm{NO}_{\mathrm{x}}$ conditions: (1) high- $\mathrm{NO}_{\mathrm{x}}$ experiments in which $\mathrm{HONO}$ is used as the $\mathrm{OH}$ precursor; and (2) low- $\mathrm{NO}_{\mathrm{x}}$ experiments in which $\mathrm{H}_{2} \mathrm{O}_{2}$ is used as the $\mathrm{OH}$ precursor. For all hydrocarbons, considerably more $\mathrm{SOA}$ is formed under low- $\mathrm{NO}_{\mathrm{x}}$ than high- $\mathrm{NO}_{\mathrm{x}}$ conditions (Figs. 3-7). Under high- $\mathrm{NO}_{\mathrm{x}}$ conditions, the SOA yields from $m$-xylene and toluene photooxidation are about $10 \%$; they are $36 \%$ and $30 \%$, respectively, under low- $\mathrm{NO}_{\mathrm{x}}$ conditions. Similar $\mathrm{NO}_{\mathrm{x}}$ dependences have been observed in other SOA-forming systems (Hatakeyama et al., 1991; Zhang et al., 1992; Hurley et al., 2001; Johnson et al., 2004; Song et al., 2005; Presto et al., 2005; Kroll et al., 2006). Since $\mathrm{O}_{3}$ and $\mathrm{NO}_{3}$ are not formed appreciably under either set of conditions, oxidation is dominated by $\mathrm{OH}$ radi- cals for all experiments, so this $\mathrm{NO}_{\mathrm{x}}$ effect cannot be a result of differences in relative oxidant levels (Hurley et al., 2001). Instead the $\mathrm{NO}_{\mathrm{x}}$ level likely governs the fate of the organic peroxy radicals formed subsequent to the hydrocarbon-OH reaction, which in turn controls the volatility of molecular products and hence the amount of SOA formed.

Shown in Fig. 10 is the simplified mechanism of the initial steps of toluene-OH reaction, leading to the formation of condensable products. One mechanism by which $\mathrm{NO}_{\mathrm{x}}$ levels may affect the products formed in the oxidation of aromatic hydrocarbons is by reaction with the aromatic- $\mathrm{OH}$ adduct. The aromatic- $\mathrm{OH}$ adduct reacts predominately with $\mathrm{O}_{2}$ under atmospheric conditions. Under very high levels of $\mathrm{NO}_{\mathrm{x}}$ (ppm levels), the adduct+NO can still be neglected (Koch et al., 2006) while the adduct $+\mathrm{NO}_{2}$ reaction increases in importance, leading to nitrogen-containing ring-retaining products such as nitrobenzene and nitrotoluene (Atkinson et al., 1989; Atkinson and Aschmann, 1994; Koch et al., 2006). The presence of a high concentration of $\mathrm{NO}_{\mathrm{x}}$ in the chamber also has an impact on the formation yields of phenol-type compounds, possibly due to the reactions of the aromatic$\mathrm{OH}$ adduct with $\mathrm{NO}$ and $\mathrm{NO}_{2}$. For example, the phenol yield from benzene photooxidation starts to decrease dramatically for $\left[\mathrm{NO}_{2}\right]>100 \mathrm{ppb}$ (Volkamer et al., 2002). In the current work, photooxidation of $m$-xylene and toluene is carried out in the presence of $\sim 500 \mathrm{ppb}$ each of $\mathrm{NO}$ and $\mathrm{NO}_{2}$; while for photooxidation of benzene the initial $\mathrm{NO}_{2}$ concentration is $<100 \mathrm{ppb}$. At these $\mathrm{NO}_{\mathrm{x}}$ levels, the reaction of the aromatic$\mathrm{OH}$ adduct with $\mathrm{NO}_{2}$ is not expected to be significant (Volkamer et al., 2002; Koch et al., 2006), so such reactions cannot be responsible for the observed effect of $\mathrm{NO}_{\mathrm{x}}$ on SOA yield.

Reaction of the aromatic-OH adduct with $\mathrm{O}_{2}$ results in the formation of peroxy radicals. Theoretical studies have shown that the peroxy radicals preferentially cyclize to form bicyclic radicals, which then react with $\mathrm{O}_{2}$ to form bicyclic peroxy radicals (Andino et al., 1996; Lay et al., 1996; Suh et al., 2003; Fan et al., 2006), even in the presence of ppm levels of NO (Zhao et al., 2005; Fan et al., 2006). Because of the high energy barrier, the isomerization of bicyclic radicals to form epoxide radicals is unlikely for toluene; only a small of 
fraction of expoxy carbonyls are observed in $m$-xylene photooxidation, suggesting that the epoxide radical channel is not important either (Suh et al., 2003; Zhao et al., 2005). As is typical for $\mathrm{RO}_{2}$ radicals, the fate of the bicyclic peroxy radicals depends mainly on the relative concentrations of $\mathrm{NO}, \mathrm{HO}_{2}$, and $\mathrm{RO}_{2}$. At the two limiting $\mathrm{NO}_{\mathrm{x}}$ conditions of this study, the peroxy radical chemistry is straightforward; under high- $\mathrm{NO}_{\mathrm{x}}$ conditions, $\mathrm{RO}_{2}$ reacts virtually entirely with $\mathrm{NO}$, as $\mathrm{NO}$ concentration is high throughout the entire experiment, while under low- $\mathrm{NO}_{\mathrm{x}}$ conditions, $\mathrm{RO}_{2}$ reacts predominantly with $\mathrm{HO}_{2}$. Based on the Master Chemical Mechanism version 3.1 (MCM v 3.1, http://www.chem. leeds.ac.uk/Atmospheric/MCM/mcmproj.html), a simple kinetic simulation shows that under low- $\mathrm{NO}_{\mathrm{x}}$ conditions, the $\mathrm{RO}_{2}+\mathrm{RO}_{2}$ reaction accounts for less than $1 \%$ of the $\mathrm{RO}_{2}$ reacted because of the relative reaction rate constants $\left(k_{\mathrm{RO} 2+\mathrm{RO} 2}=8.8 \times 10^{-13} \mathrm{~cm}^{3}\right.$ molecule $^{-1} \mathrm{~s}^{-1}$, $k_{\mathrm{RO} 2+\mathrm{HO} 2}=2.3 \times 10^{-11} \mathrm{~cm}^{3}$ molecule ${ }^{-1} \mathrm{~s}^{-1}$ ) as well as the high $\mathrm{HO}_{2}$ concentration. Thus the larger SOA yields obtained under low- $\mathrm{NO}_{\mathrm{x}}$ conditions imply that the products formed via the $\mathrm{RO}_{2}+\mathrm{HO}_{2}$ partition much more readily into the aerosol phase than those formed via the $\mathrm{RO}_{2}+\mathrm{NO}$ reaction. This conclusion is the same as that reached by previous studies (Hatakeyama et al., 1991; Johnson et al., 2004, 2005; Presto et al., 2005; Kroll et al., 2006). That SOA yields are constant under low- $\mathrm{NO}_{\mathrm{x}}$ conditions implies that the SOA formed by this channel is effectively nonvolatile under the range of $M_{o}\left(>10 \mu \mathrm{g} \mathrm{m}^{-3}\right)$ studied. It is possible that under lower SOA loadings the yields may decrease as some of the products partition back into the gas phase.

In the classical photooxidation experiments carried out in this study and by other researchers (Izumi and Fukuyama, 1990; Hurley et al., 2001; Johnson et al., 2004; MartinRevíejo and Wirtz, 2005; Song et al., 2005), an "induction period", a delay between the onset of oxidation and SOA formation, was observed. This too is a likely result of the role of $\mathrm{NO}_{\mathrm{x}}$ in peroxy radical chemistry, and hence in product volatility and SOA formation. As illustrated in Fig. 2a, only when [NO] approaches zero does aerosol growth commence. As [NO] approaches zero (from the $\mathrm{RO}_{2}+\mathrm{NO}$ and $\mathrm{HO}_{2}+\mathrm{NO}$ reactions), the $\mathrm{RO}_{2}+\mathrm{HO}_{2}$ reaction starts to compete with the $\mathrm{RO}_{2}+\mathrm{NO}$ reaction. The fraction of $\mathrm{RO}_{2}$ which reacts with $\mathrm{HO}_{2}$, $k_{\mathrm{RO} 2+\mathrm{HO} 2}\left[\mathrm{HO}_{2}\right] /\left(k_{\mathrm{RO} 2+\mathrm{NO}}[\mathrm{NO}]+k_{\mathrm{RO} 2+\mathrm{HO}_{2}}\left[\mathrm{HO}_{2}\right]\right)$, can be calculated based on the rate reaction rate constants $\left(k_{\mathrm{RO} 2+\mathrm{HO} 2}=2.3 \times 10^{-11} \mathrm{~cm}^{3}\right.$ molecule ${ }^{-1} \mathrm{~s}^{-1} ; k_{\mathrm{RO} 2+\mathrm{NO}}$ $=8.5 \times 10^{-12} \mathrm{~cm}^{3}$ molecule $\left.{ }^{-1} \mathrm{~s}^{-1}\right)(\mathrm{MCM} \vee 3.1)$. For instance, at $\sim 1 \mathrm{ppb}$ of $\mathrm{NO}$, it only requires $42 \mathrm{ppt}$ of $\mathrm{HO}_{2}$ for $10 \%$ of the $\mathrm{RO}_{2}$ to react via $\mathrm{RO}_{2}+\mathrm{HO}_{2}$. Thus it is likely that initial SOA formation results from the $\mathrm{RO}_{2}+\mathrm{HO}_{2}$ reaction, consistent with the simulations of SOA formation from classical photooxidation experiments of toluene (Johnson et al., 2004). To further study the role of peroxy radical chemistry in the "induction period", in one of the experiments additional NO was injected after its initial consumption. SOA growth slows down immediately. This provides strong evidence that the presence of NO suppresses the formation of relatively nonvolatile hydroperoxides (and hence further reactions of hydroperoxides) from the $\mathrm{RO}_{2}+\mathrm{HO}_{2}$ reaction and results in a lower SOA yield (Johnson et al., 2004, 2005).

The time-dependent growth curves for benzene photooxidation under high- and low- $\mathrm{NO}_{\mathrm{x}}$ conditions exhibit the same trend as that of $m$-xylene and toluene, in which more SOA is formed under low- $\mathrm{NO}_{\mathrm{x}}$ conditions. Martin-Revíejo and Wirtz (2005) studied the formation of SOA from benzene photooxidation under different $\mathrm{NO}_{\mathrm{x}}$ conditions. However, as the $\mathrm{NO}_{\mathrm{x}}$ dependence of SOA formation was not systematically studied, it is difficult to draw a definite conclusion on the effect of $\mathrm{NO}_{\mathrm{x}}$ on SOA yields from their data. Additionally, the experimental conditions are somewhat different; in particular, the experiments in that study were performed in the absence of seed aerosol while in the current work ammonium sulfate seed aerosol is employed. Kroll et al. (2007) find that SOA yields from the photooxidation of aromatic hydrocarbons are lower when inorganic seed particles are not present initially. The absence of seed particles results in a period in which the hydrocarbon is reacted but no aerosol is formed. The length of the "seed induction period" (and hence the amount of hydrocarbon reacted in this period, $\triangle \mathrm{HC}$ ) is likely to be affected by the $\mathrm{NO}_{\mathrm{x}}$ levels. Thus the aerosol yields $\left(\Delta M_{o} / \Delta \mathrm{HC}\right)$ obtained by Martin-Revíejo and Wirtz (2005) under different $\mathrm{NO}_{\mathrm{x}}$ conditions may be affected by this "seed induction period" and cannot be directly compared.

\subsection{Effect of oxidation rate}

Under high- $\mathrm{NO}_{\mathrm{x}}$ conditions, using $\mathrm{HONO}$ as an $\mathrm{OH}$ source, we observe SOA formation even when [NO] is several hundreds of ppb (Fig. 1). This is in contrast to results from classical photooxidation experiments, in which essentially no SOA is generated at high $\mathrm{NO}_{\mathrm{x}}$ levels, as observed both in the present study (Fig. 2b) and in work by other researchers (Johnson et al., 2004; Song et al., 2005).

The observation of SOA at high $\mathrm{NO}_{\mathrm{x}}$ levels suggests that products from the $\mathrm{RO}_{2}+\mathrm{NO}$ reactions, such as organic nitrates, are indeed condensable; however they apparently do not partition into the aerosol phase appreciably in the classical photooxidation experiments. A major difference between the HONO experiments (Fig. 1) and classical oxidation experiments (e.g. Fig. 2) is $\mathrm{OH}$ level, and hence oxidation rate. $\mathrm{HONO}$ photolysis is an efficient source of $\mathrm{OH}$ in the wavelength range of our blacklights; thus there is a burst of $\mathrm{OH}$ once the lights are turned on, resulting in a rapid rate of $m$ xylene oxidation. In the classical photooxidation experiment, $\mathrm{OH}$ is generated mainly from recycling through $\mathrm{NO}_{\mathrm{x}}$ and $\mathrm{HO}_{\mathrm{x}}$ cycles, and $\mathrm{OH}$ concentrations are generally far lower than in the HONO experiments. The large difference in SOA formation in these two cases suggests that SOA yields are 


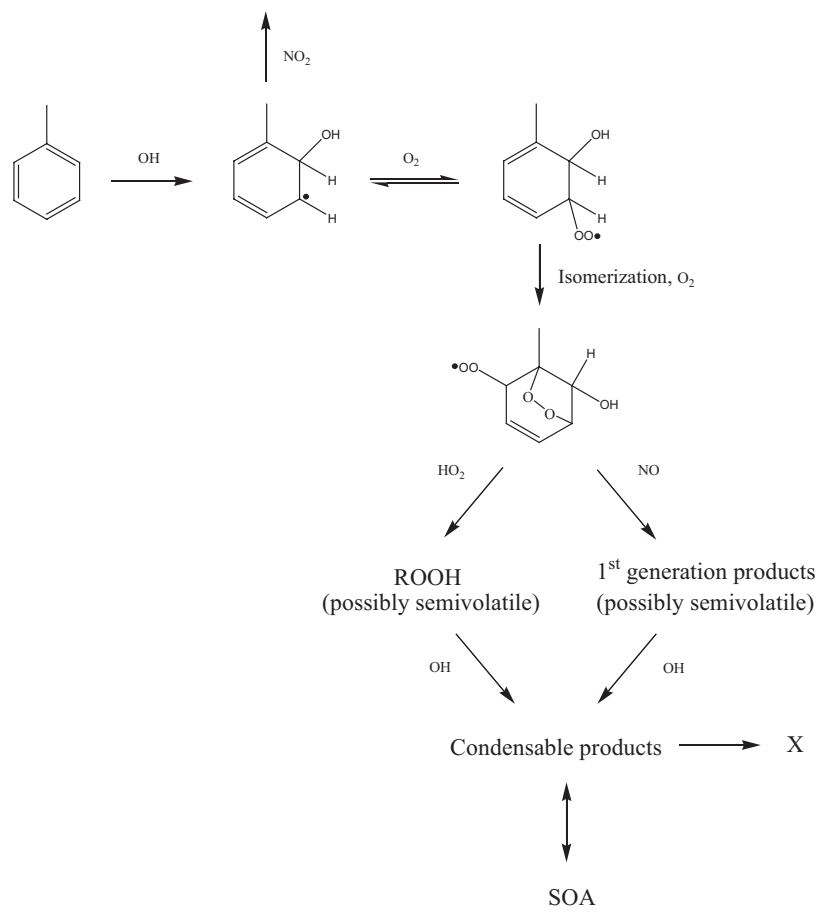

Fig. 10. A simplified SOA formation mechanism for toluene photooxidation. $\mathrm{X}$ represents the generic non particle-phase product from all gas-phase loss processes.

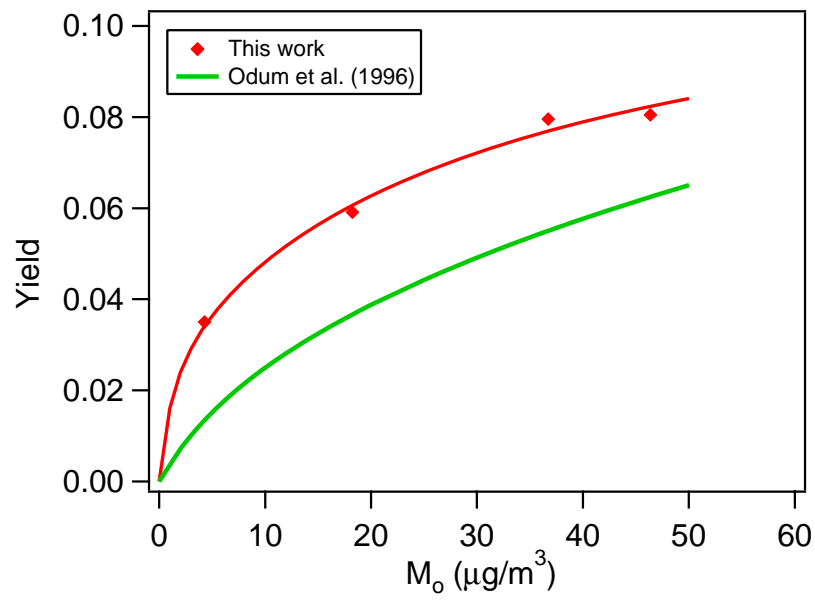

Fig. 11. Comparison of $m$-xylene high- $\mathrm{NO}_{\mathrm{x}}$ yield curve obtained in the current work to that from Odum et al. (1996). The yield curve from Odum et al. (1996) has been corrected for the temperature $\left(25^{\circ} \mathrm{C}\right)$ of this study and density $\left(1.48 \mathrm{~g} \mathrm{~cm}^{-3}\right)$ of the SOA.

dependent on the oxidation rate, with faster oxidation rates resulting in higher SOA yields.

This "rate effect" may arise as a result of loss of semivolatiles through processes other than the simple formation and partitioning of semivolatile organics. The loss of semivolatiles has been proposed as one of the mechanisms for higher SOA yields observed from aromatic photooxidation in the presence of seed aerosols as compared to nucleation experiments (Kroll et al., 2007). In the mechanism shown in Fig. 10, $\mathrm{X}$ represents the generic non particlephase product of all gas-phase loss processes. Possibilities include loss of organic species to the chamber walls, photolysis, and further reactions to form volatile products. With a rapid oxidation rate, the gas-phase concentration of semivolatiles (formed, for example, from the $\mathrm{RO}_{2}+\mathrm{NO}$ reaction) increases quickly, and the high concentrations of semivolatiles ensure that aerosol growth ensues even in the presence of semivolatile loss processes (i.e. paths not forming SOA). On the other hand, in classical photooxidation experiments, the slower formation of semivolatiles in the presence of semivolatile sinks will lead to lower SOA growth. If the dominant loss of semivolatiles is deposition to the chamber walls, then conditions in which the effect of wall loss is minimized (i.e. when the reaction is fastest) are expected to be most representative of atmospheric SOA formation. Recently, the effect of particle- and gas-phase reactions of semivolatile products on SOA formation has been examined in a modeling study by Chan et al. (2007), in which the experimental data presented in this work (among other literature data) are fitted to simple kinetic models. Given the importance of the loss of semivolatiles, these loss processes merit further investigation and experimental evidence.

This rate effect also can explain higher SOA yields in the high- $\mathrm{NO}_{\mathrm{x}}$ experiments (HONO) compared to the classical photooxidation experiments (Odum et al., 1996), illustrated in Fig. 11. Several classical photooxidation experiments with similar $\mathrm{NO}_{\mathrm{x}}$ levels as in Odum et al. (1996) were performed in the present study, with SOA yields comparable to those of Odum et al. (1996). The aerosol yields from Odum et al. (1996) were obtained at a temperature of $35-40^{\circ} \mathrm{C}$ with an assumed SOA density of $1 \mathrm{~g} \mathrm{~cm}^{-3}$. In Fig. 11, the yield curve from Odum et al. (1996) has been adjusted based on the temperature $\left(25^{\circ} \mathrm{C}\right)$ and SOA density $\left(1.48 \mathrm{~g} \mathrm{~cm}^{-3}\right)$ obtained in this study. The enthalpy of vaporization employed to convert the SOA yields from the higher temperature in Odum et al. (1996) to the lower temperature in this study is assumed to be $42 \mathrm{~kJ} \mathrm{~mol}^{-1}$ (Chung and Seinfeld, 2002), which is in the range of limited experimental data (Offenberg et al., 2006). The $\mathrm{NO}_{\mathrm{x}}$ concentrations (several hundreds of $\mathrm{ppb}$ ) used by Odum et al. (1996) are lower than those in the current experiments $(\sim 1 \mathrm{ppm})$. The higher SOA yields obtained here suggest that the enhancement in SOA yield from a faster oxidation rate is greater than the suppression in SOA yield at a higher $\mathrm{NO}_{\mathrm{x}}$ concentration.

Significant SOA formation from the rapid oxidation of aromatics under high (ppm) levels of $\mathrm{NO}_{\mathrm{x}}$ has also been observed by Stroud et al. (2004), using isopropyl nitrite as an $\mathrm{OH}$ source to oxidize toluene. Such results could not be reproduced in the simulations of Johnson et al. (2004), which predicted no SOA formation in the presence of such high $\mathrm{NO}_{\mathrm{x}}$ levels, as the $\mathrm{RO}_{2}+\mathrm{NO}$ reaction products were found 
to be too volatile to partition substantially into the aerosol phase. However, the present work suggests that products of the $\mathrm{RO}_{2}+\mathrm{NO}$ reaction are in fact condensable, but contribute to aerosol mass only when oxidation reactions are fast, minimizing the effect of other loss processes. This underscores the need for a better understanding of the behavior of semivolatile organics in the atmosphere, in terms of both physical properties (partitioning coefficients) and chemical reactions (reactive loss processes).

Finally, we note that the pair of high- $\mathrm{NO}_{\mathrm{x}}$ experiments (Fig. 1 and Fig. 2b) also provides insight into the extent to which the hydrocarbon/ $/ \mathrm{NO}_{\mathrm{x}}\left(\mathrm{HC} / \mathrm{NO}_{\mathrm{x}}\right)$ ratio characterizes the $\mathrm{NO}_{\mathrm{x}}$ level in chamber experiments. Song et al. (2005), for example, report a series of classical photooxidation experiments to study the effect of $\mathrm{HC} / \mathrm{NO}_{\mathrm{x}}$ ratio on SOA formation from $m$-xylene. It was found that aerosol yields increase with increasing $\mathrm{HC} / \mathrm{NO}_{\mathrm{x}}$ ratio (i.e. more aerosol growth at lower $\mathrm{NO}_{\mathrm{x}}$ levels), which is consistent with the present study. However, the experiments in Fig. 1 and $2 b$ have essentially similar $\mathrm{HC} / \mathrm{NO}_{\mathrm{x}}$ ratios but exhibit very different SOA growth. Therefore, while the $\mathrm{HC} / \mathrm{NO}_{\mathrm{x}}$ ratio may be a useful metric for photochemistry for experiments with similar oxidation conditions, it is less useful when comparing systems with very different oxidative conditions, as both oxidation rate and fate of peroxy radicals may differ. Given the importance of the peroxy radical in SOA formation, the $\mathrm{NO} / \mathrm{HO}_{2}$ ratio would be the more appropriate measure of different $\mathrm{NO}_{\mathrm{x}}$ levels (Kroll et al., 2006), although continuous measurement of $\mathrm{HO}_{2}$ is not currently feasible.

\subsection{General mechanism of SOA formation}

Despite uncertainties in the detailed chemical mechanism of aromatic photooxidation beyond the initial peroxy radical chemistry, we can gain insights into the general SOA formation mechanism and growth kinetics from the shapes of the growth curves under both high- $\mathrm{NO}_{\mathrm{x}}$ and low- $\mathrm{NO}_{\mathrm{x}}$ conditions (Figs. 3-7). Such curves allow for the identification of the rate-determining steps in SOA formation $(\mathrm{Ng}$ et al., 2006). In cases where the initial oxidation step determines the rate of SOA formation (condensable products are firstgeneration, or are formed extremely rapidly after the initial oxidation), SOA is formed at the same rate of hydrocarbon oxidation, and aerosol growth ceases once the parent hydrocarbon is consumed. In this case, time-dependent growthcurves from experiments with different initial hydrocarbon concentrations would overlap, as is the case for $\alpha$-pinene ozonolysis ( $\mathrm{Ng}$ et al., 2006). On the other hand, when there are further rate-limiting steps to the formation of condensable products, there is a time lag between hydrocarbon oxidation and SOA formation and the growth curve exhibits a vertical section at the end, as is the case for the ozonolysis and photooxidation of compounds with multiple double bonds $(\mathrm{Ng}$ et al., 2006).
Figures 3-7 show the time-dependent growth curves for $m$-xylene, toluene, and benzene photooxidation under high$\mathrm{NO}_{\mathrm{x}}$ and low- $\mathrm{NO}_{\mathrm{x}}$ conditions. In all cases, SOA growth is observed immediately after photooxidation commences, resulting in a smooth growth curve from the onset of oxidation. Some hydrocarbon remains unreacted by the end of these experiments. In experiments in which all the hydrocarbon is reacted (not shown), no vertical section in the growth curve is observed, indicating there is no further SOA formation after the complete consumption of the parent hydrocarbon. This indicates that the first oxidation step (oxidation of the parent hydrocarbon) governs the rate of SOA formation.

However, unlike with $\alpha$-pinene ozonolysis ( $\mathrm{Ng}$ et al., 2006), the time-dependent growth curves from experiments with different initial aromatic hydrocarbon concentrations do not overlap, and aerosol growth is not the same for a given amount of hydrocarbon reacted $(\Delta \mathrm{HC})$. Instead, SOA growth at a given value of $\triangle \mathrm{HC}$ depends on the initial hydrocarbon concentration $\left(\mathrm{HC}_{0}\right)$ : experiments with higher $\mathrm{HC}_{0}$ reach a given $\triangle \mathrm{HC}$ in a shorter time than those with smaller $\mathrm{HC}_{0}$. At smaller $\mathrm{HC}_{0}$, during the longer time required to reach the same $\triangle \mathrm{HC}$, the first generation products have more time to be oxidized to form condensable products. Therefore, the divergence in growth curves at different initial hydrocarbon concentrations indicates that even though the first step is the rate-limiting in SOA formation, subsequent oxidation steps also occur prior to SOA formation. As discussed in $\mathrm{Ng}$ et al. (2006), if subsequent oxidation steps are essentially instantaneous relative to the initial oxidation step, then SOA formation can be treated as a single step and all the growth curves will overlap. In the present study, the growth curves diverge only slightly, indicating that although the second oxidation step in not instantaneous, it is still substantially faster than the initial oxidation step. The formation of SOA by multiple oxidation steps, in which the later steps are substantially faster than the initial oxidation, is consistent with available kinetic data and current understanding of the photooxidation of aromatic hydrocarbons. In general, first-generation products of aromatic photooxidation react about an order of magnitude faster with $\mathrm{OH}$ than do their parent hydrocarbons (Calvert et al., 2002). For example, whereas the benzene-OH rate constant is $1.22 \times 10^{-12} \mathrm{~cm}^{-3}$ molecule ${ }^{-1} \mathrm{~s}^{-1}$, the rate constant of the reaction of $\mathrm{OH}$ with phenol, a major first-generation reaction product, is $2.7 \times 10^{-11} \mathrm{~cm}^{-3}$ molecule ${ }^{-1} \mathrm{~s}^{-1}$ (Calvert et al., 2002). Our study does not exclude the possibility of formation of SOA from the condensation of first-generation products; however, it suggests that second (or further) generation products contribute significantly to SOA growth. 


\subsection{Effect of seed acidity}

To our knowledge, there are no published data on the effect of seed aerosol acidity on SOA formed from the photooxidation of aromatic VOCs. As shown in Fig. 9, seed particle acidity does not enhance the $\mathrm{SOA}$ yield under different $\mathrm{NO}_{\mathrm{x}}$ conditions. The composition of the acid and nonacid seed particles, as well as the RH $(\sim 5 \%)$, are the same as those previously employed in the study of isoprene SOA formation (Surratt et al., 2007); yet, an enhancement in SOA yield is observed for isoprene experiments but not for the aromatics. The chambers are maintained at $\mathrm{RH} \sim 5 \%$ in this study and so the nonacid seed particles are dry, whereas for acidic seed particles some water might be present. If aerosol water is essential for the acidity effect, its absence might explain the lack of an observed effect in the current study. The dependence of SOA growth on RH is beyond the scope of this work but warrants future investigation.

\section{Implication for SOA growth from aromatic hydrocar- bons}

We report a series of chamber experiments investigating the $\mathrm{NO}_{\mathrm{x}}$ dependence and effect of seed aerosol acidity on SOA formation from the photooxidation of aromatic compounds. High- $\mathrm{NO}_{\mathrm{x}}$ experiments are performed with $\mathrm{HONO}$ as the $\mathrm{OH}$ precursor at initial $\mathrm{NO}_{\mathrm{x}}$ of $\sim 1 \mathrm{ppm}$. By performing experiments with $\mathrm{HONO}$, SOA is formed under truly high- $\mathrm{NO}_{\mathrm{x}}$ conditions, as the NO concentration remains high throughout the entire experiment. In low- $\mathrm{NO}_{\mathrm{x}}$ experiments, $\mathrm{H}_{2} \mathrm{O}_{2}$ is used as the $\mathrm{OH}$ precursor and the initial $\mathrm{NO}_{\mathrm{x}}$ is $<1 \mathrm{ppb}$. For each of the aromatic hydrocarbons studied ( $m$-xylene, toluene, and benzene), the SOA yields under low- $\mathrm{NO}_{\mathrm{x}}$ conditions are significantly larger than those under high- $\mathrm{NO}_{\mathrm{x}}$ conditions; this is likely a result of the competition between $\mathrm{RO}_{2}+\mathrm{NO}$ and $\mathrm{RO}_{2}+\mathrm{HO}_{2}$ reactions, similar to what has been observed in other studies (Hatakeyama et al., 1991; Johnson et al., 2004, 2005; Presto et al., 2005; Kroll et al., 2006).

In assessing the contribution of aromatic compounds to total ambient SOA, it is important that laboratory conditions are representative of those in the atmosphere. The aromatic SOA yield parameters $\left(\alpha_{i}\right.$ and $\left.K_{o m, i}\right)$ currently employed in atmospheric models are those obtained by Odum et al. (1996, 1997a, b) almost a decade ago by irradiation of hydrocarbon/ $\mathrm{NO}_{\mathrm{x}}$ mixtures. With the profound dependence of $\mathrm{NO}_{\mathrm{x}}$ on SOA formation, it is necessary that the effect of $\mathrm{NO}_{\mathrm{x}}$ on SOA yields be included in atmospheric models. For instance, compounds like benzene are mainly emitted in source-rich regions; with its slow reactivity, however, benzene can be transported to areas with a lower $\mathrm{NO}_{\mathrm{x}}$ level before it react substantially, resulting in a higher SOA yield than if it reacted in the immediate vicinity of its sources. By performing experiments at two extreme $\mathrm{NO}_{\mathrm{x}}$ conditions, we are able to obtain SOA yield parameters under high- and low- $\mathrm{NO}_{\mathrm{x}}$ conditions, allowing for the parameterization of the $\mathrm{NO}_{\mathrm{x}}$ dependence for atmospheric models, based upon the reactivity of organic peroxy radicals. Other than the $\mathrm{NO}_{\mathrm{x}}$ effect, the loss of semivolatiles also affects the SOA yields measured. The depletion of semivolatiles by chemical reaction or wall loss may lead to lower SOA formation in the chambers than occurs in the atmosphere. Due to the slower oxidation rate in the classical photooxidation experiments conducted by Odum et al. (1996, 1997a, b), it is likely that their SOA yield parameters underestimate SOA formation from aromatic hydrocarbons in the atmosphere.

Finally, detailed analysis of the chemical composition of aromatic SOA will assist in unraveling the detailed aromatic SOA formation mechanism under both high and low- $\mathrm{NO}_{\mathrm{x}}$ conditions. In a forthcoming publication, the chemical composition of aromatic SOA will be explored. Since a wide array of sulfate esters are observed only when acidified inorganic seed aerosols are employed (Surratt et al., 2007), the chemical composition of the SOA formed in nonacid/acid seed experiments may also provide insights into the lack of a seed acidity effect on SOA yields in the present study.

Acknowledgements. This research was funded by the U.S. Environmental Protection Agency Science to Achieve Results (STAR) Program grant number RD-83107501-0, managed by EPA's Office of Research and Development (ORD), National Center for Environmental Research (NCER), and by U.S. Department of Energy Biological and Environmental Research Program DE-FG02-05ER63983.

Edited by: S. Martin

\section{References}

Andino, J. M., Smith, J. N., Flagan, R. C., Goddard III, W. A., and Seinfeld, J. H.: Mechanism of atmospheric photooxidation of aromatics: A theoretical study, J. Phys. Chem., 100, $10967-$ $10980,1996$.

Atkinson, R., Aschmann, S. M., Arey, J., and Carter, W. P. L.: Formation of ring-retaining products from the $\mathrm{OH}$ radical-initiated reactions of benzene and toluene, Int. J. Chem. Kinet., 21, 801827, 1989.

Atkinson, R. and Aschmann, S. M.: Products of the gas-phase reactions of aromatic hydrocarbons: effect of $\mathrm{NO}_{2}$ concentration, Int. J. Chem. Kinet., 26, 929-944, 1994.

Bahreini, R., Keywood, M. D., Ng, N. L., Varutbangkul, V., Gao, S., Flagan, R. C., and Seinfeld, J. H.: Measurements of secondary organic aerosol (SOA) from oxidation of cycloalkenes, terpenes, and $\mathrm{m}$-xylene using an Aerodyne aerosol mass spectrometer, Environ. Sci. Technol., 39, 5674-5688, 2005.

Calvert, J. G., Atkinson, R., Becker, K. H., Kamens, R. M., Seinfeld, J. H., Wallington, T. J., and Yarwoord, G.: The Mechanisms of Atmospheric Oxidation of Aromatic Hydrocarbons, Oxford University Press, New York, 556pp., 2002.

Chan, A. W. H., Kroll, J. H., Ng, N. L., and Seinfeld, J. H.: Kinetic modeling of secondary organic aerosol formation: effects of particle- and gas-phase reactions of semivolatile products, At- 
mos. Chem. Phys. Discuss., 7, 7051-7085, 2007, http://www.atmos-chem-phys-discuss.net/7/7051/2007/.

Chung, S. H. and Seinfeld, J. H.: Global distribution and climate forcing of carbonaceous aerosols, J. Geophys. Res., 107, 4407, doi:10.1029/2001JD001397, 2002.

Cocker III, D. R., Flagan, R. C., and Seinfeld, J. H.: State-of-theart chamber facility for studying atmospheric aerosol chemistry, Environ. Sci. Technol., 35, 2594-2601. 2001.

de Gouw, J. A., Middlebrook, A. M., Warneke, C., Goldan, P. D., Kuster, W. C., Roberts, J. M., Fehsenfeld, F. C., Worsnop, D. R., Canagaratna, M. R., Pszenny, A. A. P., Keene, W. C., Marchewka, M., Bertman, S. B., and Bates, T. S.: Budget of organic carbon in a polluted atmosphere: Results from the New England Air Quality Study in 2002, J. Geophys. Res., 110, D16305, doi:10.1029/2004JD005623, 2005.

Edney, E. O., Kleindienst, T. E., Jaoui, M., Lewandowski, M., Offenberg, J. H., Wang, W., and Claeys, M.: Formation of 2-methyl tetrols and 2-methylglyceric acid in secondary organic aerosol from laboratory irradiated isoprene/ $\mathrm{NO}_{\mathrm{x}} / \mathrm{SO}_{2}$ /air mixtures and their detection in ambient $\mathrm{PM}_{2.5}$ samples collected in the eastern United States, Atmos. Environ., 39, 5281-5289, 2005.

Fan, J. and Zhang, R.: Atmospheric oxidation mechanism of $p$ xylene: A density function theory study, J. Phys. Chem. A, 110, 7728-7737, 2006.

Forstner, H. J. L., Flagan, R. C., and Seinfeld, J. H.: Secondary organic aerosol from the photooxidation of aromatic hydrocarbons: Molecular composition, Environ. Sci. Technol., 31, 1345-1358, 1997.

Gao, S., Keywood, M. D., Ng, N. L., Surratt, J. D., Varutbangkul, V., Bahreini, R., Flagan, R. C., and Seinfeld, J. H.: Lowmolecule weight and oligomeric components in secondary organic aerosol from the ozonolysis of cycloalkenes and $\alpha$-pinene, J. Phys. Chem., A, 108, 10 147-10 164, 2004a.

Gao, S., Ng, N. L., Keywood, M. D., Varutbangkul, V., Bahreini, R., Nenes, A., He, J., Yoo, K. Y., Beauchamp, J. L., Hodyss, R. P., Flagan, R. C., and Seinfeld, J. H.: Particle phase acidity and oligomer formation in secondary organic aerosol, Environ. Sci. Technol., 38, 6582-6589, 2004b.

Hatakeyama, S., Izumi, K., Fukuyama, T., Akimoto, H., Washida, N.: Reactions of $\mathrm{OH}$ with $\alpha$-pinene and $\beta$-pinene in air: Estimates of global $\mathrm{CO}$ production from the atmospheric oxidation of terpenes, J. Geophys. Res., 96(D1), 947-958, 1991.

Heald, C. L., Jacob, D. J., Park, R. J., Russell, L. M., Huebert, B. J., Seinfeld, J. H., Liao, H., and Weber, R. J.: A large organic aerosol source in the free troposphere missing from current models, Geophys. Res. Lett., 32, L18809, doi:10.1029/2005GL023831, 2005.

Heald, C. L., Jacob, D.J., Turquety, S., Hudman, R.C., Weber, R. J., Sullivan, A.P., Peltier, R. E., Atlas, E. L., de Gouw, J.A., Warneke, C., Holloway, J. S., Neuman, J. A., F. Flocke, M., and Seinfeld, J. H.: Concentration and sources of organic carbon aerosols in the free troposphere over North America, J. Geophys. Res., 111(D23), D23S47, doi:10.1029/2006JD007705, 2006.

Hurley, M. D., Sokolov, O., Wallington, T. J., Takekawa, H., Karasawa, M., Klotz, B., Barnes, I., and Becker, K. H.: Organic aerosol formation during the atmospheric degradation of toluene, Environ. Sci. Technol., 35, 1358-1366, 2001.

Iinuma, Y., Böge, O., Gnauk, T., and Herrmann, H.: Aerosolchamber study of the pinene $/ \mathrm{O}_{3}$ reaction: Influence of particle acidity on aerosol yields and products, Atmos. Environ., 38, 761773, 2004

Izumi, K. and Fukuyama, T.: Photochemical aerosol formation from aromatic hydrocarbons in the presence of $\mathrm{NO}_{\mathrm{x}}$, Atmos. Environ., 24A, 1433-1441, 1990.

Jang, M. and Kamens, R. M.: Characterization of secondary organic aerosol from the photooxidation of toluene in the presence of $\mathrm{NO}_{\mathrm{x}}$ and 1-propene, Environ. Sci. Technol., 35, 3626-3639, 2001.

Jang, M., Czoschke, N. M., Lee, S., and Kamens, R. M.: Heterogeneous atmospheric aerosol production by acid-catalyzed particlephase reactions, Science, 298, 814-817, 2002.

Johnson, D., Jenkin, M. E., Wirtz, K., and Martín-Reviejo, M.: Simulating the formation of secondary organic aerosol from the photooxidation of toluene, Environ. Chem., 1, 150-165, 2004.

Johnson, D., Jenkin, M. E., Wirtz, K., and Martín-Reviejo, M.: Simulating the formation of secondary organic aerosol from the photooxidation of aromatic hydrocarbons, Environ. Chem., 2, 3548, 2005.

Kalberer, M., Paulsen, S., Sax, M., Steinbacher, M., Dommen, J., Prevot, A. S. H., Fisseha, R., Weingartner, E., Frankevich, V., Zenobi, R., and Baltensperger, U.: Identification of polymers as major components of atmospheric organic aerosols, Science, 303, 1659-1662, 2004.

Keywood, M. D., Varutbangkul, V., Bahreini, R., Flagan, R. C., and Seinfeld, J. H.: Secondary organic aerosol formation from the ozonolysis of cycloalkenes and related compounds, Environ. Sci. Technol., 38, 4157-4164, 2004.

Kleindienst, T. E., Conver, T. S., McIver, C. D., and Edney, E. O.: Determination of secondary organic aerosol products from the photooxidation of toluene and their implications in ambient $\mathrm{PM}_{2.5}$, J. Atmos. Chem., 47, 79-100, 2004.

Koch, R., Knispel, R., Elend, M., Siese, M., and Zetzsch, C.: Consecutive reactions of aromatic-OH adducts with $\mathrm{NO}, \mathrm{NO}_{2}$, and $\mathrm{O}_{2}$ : Benzene, toluene, $m$-and $p$-xylene, hexamethylbenzene, phenol, $m$-cresol, and aniline, Atmos. Chem. Phys. Discuss., 6, 7623-7656, 2006 http://www.atmos-chem-phys-discuss.net/6/7623/2006/.

Kroll, J. H., Ng, N. L., Murphy, S. M., Flagan, R. C., and Seinfeld, J. H.: Secondary organic aerosol formation from isoprene photooxidation, Environ. Sci. Technol., 40, 1869-1877, 2006.

Kroll, J., Chan, A. W. H., Ng, N. L., Flagan, R. C., and Seinfeld, J. H.: Reactions of semivolatile organics and their effects on secondary organic aerosol formation, Environ. Sci. Technol., 41, 3545-3550, 2007.

Lay, T. H., Bozzelli, J. W., and Seinfeld, J. H.: Atmospheric photochemical oxidation of benzene: Benzene+OH and the benzeneOH adduct, J. Phys. Chem., 100, 6543-6554, 1996.

Martin-Revíejo, M. and Wirtz, K.: Is benzene a precursor for secondary organic aerosol? Environ. Sci. Technol., 39, 1045-1054, 2005.

Ng, N. L., Kroll, J. H., Keywood, M. D., Bahreini, R., Varutbangkul, V., Flagan, R. C., Seinfeld, J. H., Lee, A., and Goldstein, A. H.: Contribution of first- versus second-generation products to secondary organic aerosols formed in the oxidation of biogenic hydrocarbons, Environ. Sci. Technol., 40, 2283-2297, 2006.

Odum, J. R., Hoffmann, T., Bowman, F., Collins, D., Flagan, R. C., and Seinfeld, J. H.: Gas/particle partitioning and secondary 
organic aerosol yields, Environ. Sci. Technol., 30, 2580-2585, 1996.

Odum, J. R., Jungkamp, T. P. W., Griffin, R. J., Flagan, R. C., and Seinfeld, J. H.: The atmospheric aerosol-forming potential of whole gasoline vapor, Science, 276, 96-99, 1997a.

Odum, J. R., Jungkamp, T. P. W., Griffin, R. J., Forstner, H. J. L., Flagan, R. C., and Seinfeld, J. H.: Aromatics, reformulated gasoline and atmospheric organic aerosol formation, Environ. Sci. Technol., 31, 1890-1897, 1997b.

Offenberg, J. H., Kleindienst, T. E., Jaoui, M., Lewandowski, M., and Edney, E. O.: Thermal properties of secondary organic aerosols, Geophys. Res. Lett., 33, L03816, doi:10.1029/2005GL024623, 2006.

Presto, A. A., Huff Hartz, K. E., and Donahue, N. M.: Secondary organic aerosol production from ozonolysis: 2. Effect of $\mathrm{NO}_{\mathrm{x}}$ concentration, Environ. Sci. Technol., 39, 7046-7054, 2005.

Presto, A. A. and Donahue, N. M.: Investigation of $\alpha$-pinene+ozone secondary organic aerosol formation at low total aerosol mass, Environ. Sci. Technol., 40, 3536-3543, 2006.

Seinfeld, J. H. and Pandis, S. N.: Atmospheric Chemistry and Physics: From Air Pollution to Climate Change, Wiley, New Jersey, 1203pp., 2006.

Song, C., Na, K., and Cocker III, D. R.: Impact of the hydrocarbon to $\mathrm{NO}_{\mathrm{x}}$ ratio on secondary organic aerosol formation, Environ. Sci. Technol, 39, 3143-3149, 2005.

Stroud, C. A., Makar, P. A., Michelangeli, D. V., Mozurkewich, M., Hastie, D. R., Barbu, A., and Humble, J.: Simulating organic aerosol formation during photooxidation of toluene $/ \mathrm{NO}_{\mathrm{x}}$ mixtures: Comparing the equilibrium and kinetic assumption, Environ. Sci. Technol., 38, 1471-1479, 2004.
Suh, I., Zhang, R., Molina, L. T., and Molina, M. J.: Oxidation mechanism of aromatic peroxy and bicyclic radicals from $\mathrm{OH}-$ toluene reactions, J. Am. Chem. Soc., 125, 12 655-12 665, 2003.

Surratt, J. D., Kroll, J. H., Kleindienst, T. E., Edney, E. O., Claeys, M., Sorooshian, A., Ng, N. L., Offenberg, J. H., Lewandowski, M., Jaoui, M., Flagan, R. C., and Seinfeld, J. H.: Evidence for organosulfates in secondary organic aerosol, Environ. Sci. Technol., 41, 517-527, 2007.

Tolocka, M. P., Jang, M., Ginter, J. M., Cox, F. J., Kamens, R. M., and Johnston M. V.: Formation of oligomers in secondary organic aerosol, Environ. Sci. Technol., 38, 1428-1434, 2004.

Tsigaridis, K. and Kanakidou, M.: Global modelling of secondary organic aerosols in the troposphere: A sensitivity study, Atmos. Chem. Phys., 3, 1849-1869, 2003, http://www.atmos-chem-phys.net/3/1849/2003/.

Volkamer, R., Klotz, B., Barnes, I., Imamura, T., Wirtz, K., Washida, N., Becker, K. H., and Platt, U.: OH-initiated oxidation of benzene, Part I, phenol formation under atmospheric conditions, Phys. Chem. Chem. Phys., 4, 1589-1610, 2002.

Volkamer, R., Jimenez, J. L., San Martini, F., Dzepina, K., Zhang, Q., Salcedo, D., Molina, L. T., Worsnop, D. R., Molina, M. J.: Secondary organic aerosol formation from anthropogenic air pollution: Rapid and higher than expected, Geophys. Res. Lett., 33, L17811, doi:10.1029/2006GL026899, 2006.

Zhang, S., Shaw, M., Seinfeld, J. H., and Flagan, R. C.: Photochemical aerosol formation from $\alpha$-pinene and $\beta$-pinene, J. Geophys. Res., 97, 20 717-20 729, 1992.

Zhao, J., Zhang, R., Misawa, K., and Shibuya K.: Experimental product study of the $\mathrm{OH}$-initiated oxidation of $m$-xylene, J. Photochem Photobio A., 199-207, 2005. 